\title{
Capsaicin-Sensitive Sensory Nerves Are Necessary for the Protective Effect of Ghrelin in Cerulein-Induced Acute Pancreatitis in Rats
}

\author{
Joanna Bonior ${ }^{1}$, Zygmunt Warzecha ${ }^{2}$, Piotr Ceranowicz ${ }^{2, *}$, Ryszard Gajdosz ${ }^{3}$, \\ Piotr Pierzchalski ${ }^{1}$, Michalina Kot ${ }^{1}$, Anna Leja-Szpak ${ }^{1}$, Katarzyna Nawrot-Porąbka ${ }^{1}$, \\ Paweł Link-Lenczowski ${ }^{1}$, Michał Pędziwiatr ${ }^{4}$ (D), Rafał Olszanecki ${ }^{5}$, Krzysztof Bartuś ${ }^{6}$, \\ Rafał Trąbka ${ }^{7}$, Beata Kuśnierz-Cabala ${ }^{8}$, Artur Dembiński ${ }^{2}$ and Jolanta Jaworek ${ }^{1}$ \\ 1 Department of Medical Physiology, Faculty of Health Sciences, Jagiellonian University Medical College, \\ 12 Michałowskiego St., 31-126 Krakow, Poland; joanna.bonior@uj.edu.pl (J.B.); piotr.pierzchalski@uj.edu.pl (P.P.); \\ m.kot@uj.edu.pl (M.K.); a.leja-szpak@uj.edu.pl (A.L.-S.); k.nawrot-porabka@uj.edu.pl (K.N.-P.); \\ p.link-lenczowski@uj.edu.pl (P.L.-L.); jolanta.jaworek@uj.edu.pl (J.J.) \\ 2 Department of Physiology, Faculty of Medicine, Jagiellonian University Medical College, 16 Grzegórzecka St., \\ 31-531 Krakow, Poland; mpwarzec@cyf-kr.edu.pl (Z.W.); mpdembin@cyf-kr.edu.pl (A.D.) \\ 3 Department of Emergency Medical Care, Faculty of Health Sciences, Jagiellonian University Medical College, \\ 12 Michałowskiego St., 31-126 Krakow, Poland; ryszard.gajdosz@uj.edu.pl \\ 4 2nd Department of Surgery, Faculty of Medicine, Jagiellonian University Medical College, 21 Kopernika St., \\ 31-501 Krakow, Poland; michal.pedziwiatr@uj.edu.pl \\ 5 Department of Pharmacology, Faculty of Medicine, Jagiellonian University Medical College, \\ 16 Grzegórzecka St., 31-531 Krakow, Poland; rafal.olszanecki@uj.edu.pl \\ 6 Department of Cardiovascular Surgery and Transplantology, Faculty of Medicine, Jagiellonian University, \\ JP II Hospital, 80 Pradnicka St., 31-202 Krakow, Poland; krzysztof.bartus@uj.edu.pl \\ 7 Department of Rehabilitation, Faculty of Health Sciences, Jagiellonian University Medical College, \\ 3 Koło Strzelnicy St., 30-219 Krakow, Poland; rafal.trabka@uj.edu.pl \\ 8 Department of Diagnostics, Chair of Clinical Biochemistry, Faculty of Medicine Jagiellonian University \\ Medical College, 15 A Kopernika St., 31-501 Krakow, Poland; mbkusnie@cyf-kr.edu.pl \\ * Correspondence: piotr.ceranowicz@uj.edu.pl; Tel.: +48-12-421-10-06
}

Received: 20 May 2017; Accepted: 27 June 2017; Published: 30 June 2017

Abstract: Ghrelin was shown to exhibit protective and therapeutic effect in the gut. Aim of the study was to investigate the role of sensory nerves (SN) in the protective effect of ghrelin in acute pancreatitis (AP). Studies were performed on male Wistar rats or isolated pancreatic acinar cells. After capsaicin deactivation of sensory nerves (CDSN) or treatment with saline, rats were pretreated intraperitoneally with ghrelin or saline. In those rats, AP was induced by cerulein or pancreases were used for isolation of pancreatic acinar cells. Pancreatic acinar cells were incubated in cerulein-free or cerulein containing solution. In rats with intact $\mathrm{SN}$, pretreatment with ghrelin led to a reversal of the cerulein-induced increase in pancreatic weight, plasma activity of lipase and plasma concentration of tumor necrosis factor- $\alpha$ (TNF- $\alpha)$. These effects were associated with an increase in plasma interleukin- 4 concentration and reduction in histological signs of pancreatic damage. CDSN tended to increase the severity of AP and abolished the protective effect of ghrelin. Exposure of pancreatic acinar cells to cerulein led to increase in cellular expression of mRNA for TNF- $\alpha$ and cellular synthesis of this cytokine. Pretreatment with ghrelin reduced this alteration, but this effect was only observed in acinar cells obtained from rats with intact SN. Moreover, CDSN inhibited the cerulein- and ghrelin-induced increase in gene expression and synthesis of heat shock protein 70 (HSP70) in those cells. Ghrelin exhibits the protective effect in cerulein-induced AP on the organ and pancreatic acinar cell level. Sensory nerves ablation abolishes this effect.

Keywords: sensory nerves; inflammation; acute pancreatitis; capsaicin; lipase; interleukin-4; tumor necrosis factor- $\alpha$; heat shock protein 70 


\section{Introduction}

Ghrelin is a 28-amino acid peptide originally isolated from the rat and human stomach and is formed from a 117-amino acid precursor [1-3]. Ghrelin acts via ghrelin receptor. Before the discovery of ghrelin this receptor was called growth hormone secretagogue receptor-GHS-R [1,3,4]. Early studies in humans and animals showed that ghrelin strongly stimulates the release of growth hormone from the pituitary gland [1]. This effect is a result of direct action of ghrelin on ghrelin receptors present on pituitary somatotrophs; however, ghrelin also stimulates the liberation of growth hormone indirectly by acting on growth hormone-releasing hormone $(\mathrm{GH}-\mathrm{RH})$ positive cells in the hypothalamus triggering GH-RH secretion [5]. In turn, GH-RH acting on the anterior part of the pituitary gland promotes the release of growth hormone. Another early discovered function of ghrelin is its effect on the energy balance of the body. Ghrelin induces body mass gain by increase in food intake and decrease in fat utilization $[3,6,7]$.

The ghrelin receptor is present mainly in the pituitary gland and hypothalamus, but its existence was also found in other tissues of the body such as the thyroid gland, pancreas, spleen, myocardium, adrenal gland, gonad, heart, lung and cells of the immunological system [8-10]. Previous studies showed that ghrelin exhibits protective and therapeutic effect in the digestive tract. Pretreatment with this polypeptide inhibits the development of different experimental models of gastric lesions [11-13], as well as exhibits therapeutic effect in the course of oral [14], gastric [15,16] and duodenal [15,17] ulcers. In addition, most experimental studies on the role of ghrelin in colitis indicates that administration of this peptide exhibits protective and therapeutic effect in the large bowel [18-23]. Protective and therapeutic effect of ghrelin was also found in the pancreas. Pretreatment with ghrelin inhibits the development of acute pancreatitis induced by cerulein [24], taurocholate [25] and pancreatic ischemia followed by reperfusion [26]. Administration of ghrelin after induction of acute pancreatitis accelerates the recovery in this disease [27-29]. Moreover, treatment with this peptide attenuates the severity of acute lung injury in taurocholate-induced acute pancreatitis [30].

Primary unmyelinated capsaicin-sensitive sensory neurons play a nociceptive role and convey signals, mainly pain signals from the skin and internal environment of the body to the central nervous system. However, stimulation of these neurons also leads to release of neuromediators from their peripheral endings [31,32]. Capsaicin, a main pungent ingredient of chili pepper, binds to specific vanilloid (capsaicin) receptors present on capsaicin-sensitive sensory neurons [33,34]. This receptor is a nonselective cation channel and belongs to the transient receptor potential family. The current name of this receptor is the transient receptor potential vanilloid 1 (TRPV1) [33,34]. Low doses of capsaicin act on TRPV1 and stimulate primary sensory nerves by opening the nonselective cation channels. It leads to a local release of neuromediators such as calcitonin gene-related peptide (CGRP) and substance P [31-33]. In contrast, high neurotoxic doses of capsaicin lead to ablation of sensory nerves and decrease plasma and tissue level of CGRP [35]. Capsaicin-sensitive sensory nerves are involved in the maintenance of organ integrity in the gut. In the stomach, stimulation of sensory nerves by low doses of capsaicin or administration of exogenous CGRP before induction of ulcers exhibit a preventive effect in different experimental models of gastric ulcers [36,37], whereas the ablation of sensory nerves by neurotoxic doses of capsaicin aggravates gastric damage [38] and delays the healing of gastric ulcers [39].

Similar effects were observed in the pancreas. Ablation of capsaicin-sensitive sensory nerves before induction of acute pancreatitis increases the severity of this disease evoked by cerulein or pancreatic ischemia followed by reperfusion $[40,41]$. In contrast, stimulation of sensory nerves by low doses of capsaicin or pretreatment with CGRP before induction of acute pancreatitis exhibits protective effect in the pancreas and reduces the severity of cerulein- $[42,43]$ and ischemia/reperfusion-induced acute pancreatitis [41]. On the other hand, administration of CGRP after induction of acute pancreatitis or persistent activity of sensory nerves increases the severity of acute pancreatitis and lead to functional insufficiency of the pancreas typical for chronic pancreatitis [44,45]. Moreover, there are studies 
showing that activation of TRPV1 may promote neurogenic inflammation in the pancreas via a release of substance $P$ and activation of the neurokinin-1 receptor [46-48].

The aim of our present study was to investigate and compare the effect of intraperitoneal administration of ghrelin on the development of cerulein-induced acute pancreatitis in rats with intact sensory nerves or sensory nerve ablation evoked by neurotoxic doses of capsaicin. Moreover, this study was designated to assess the effect of ablation of sensory nerves and administration of ghrelin performed before isolation of pancreatic acinar cells on expression of mRNA for tumor necrosis factor- $\alpha$ (TNF- $\alpha$ ) and heat shock protein 70 (HSP70), and synthesis of those proteins by pancreatic acinar cells incubated in the cerulein-containing or cerulein-free medium.

\section{Results}

\subsection{In Vivo Studies}

Subcutaneous infusion of cerulein at a dose of $5 \mu \mathrm{g} / \mathrm{kg} / \mathrm{h}$ for $5 \mathrm{~h}(1 \mathrm{~mL} / \mathrm{h})$, caused acute edematous pancreatitis in all animals subjected to this procedure.

2.1.1. Effect of Ghrelin Administered Intraperitoneally on Pancreatic Weight and Histological Signs of Acute Pancreatitis

In rats from the control sensory nerves-intact group treated with saline, pancreatic weight reached $800 \pm 65 \mathrm{mg}$ (Figure 1). Intraperitoneal administration of increasing doses of ghrelin, 12.5, 25 or $50 \mu \mathrm{g} / \mathrm{kg}$, failed to affect significantly this parameter in sensory nerves-intact rats without induction of acute pancreatitis.

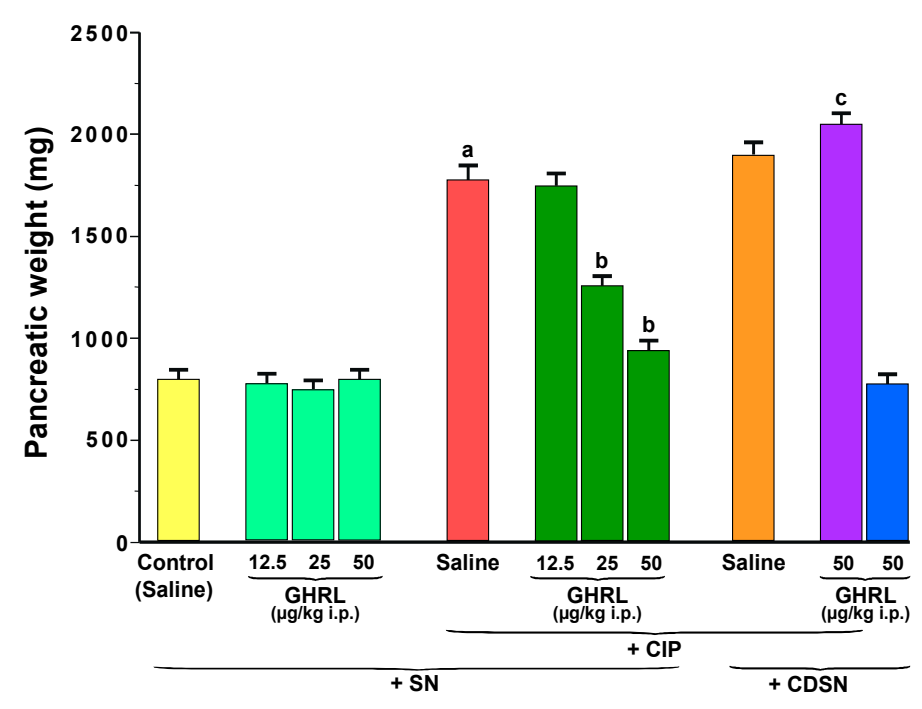

Figure 1. Effect of saline or ghrelin (GHRL) given intraperitoneally at a dose of $12.5,25$ or $50 \mu \mathrm{g} / \mathrm{kg}$ and cerulein-induced pancreatitis (CIP) on pancreatic weight in sensory nerves-intact rats (SN) or rats with capsaicin deactivation of sensory nerves (CDSN). ${ }^{a} p<0.05$ compared to the control group with intact sensory nerves and without induction of CIP; ${ }^{b} p<0.05$ compared to sensory nerves-intact rats with CIP pretreated with saline; ${ }^{\mathrm{c}} p<0.05$ compared to sensory nerves-intact rats pretreated with GHRL at a dose of $50 \mu \mathrm{g} / \mathrm{kg}$ prior to CIP. Mean \pm standard error of the mean (SEM) from values obtained from 10-15 rats in each experimental group.

Subcutaneous infusion of cerulein induced pancreatic edema and significantly increased pancreatic weight in sensory nerves-intact rats to a level of $1780 \pm 150 \mathrm{mg}$. Intraperitoneal administration of ghrelin at a doses of 25 or $50 \mu \mathrm{g} / \mathrm{kg}, 30 \mathrm{~min}$ prior to the commencement of cerulein infusion, resulted in a statistically significant reduction in the cerulein-induced increase in pancreatic weight in rats with intact sensory nerves, to a level of $1259 \pm 95 \mathrm{mg}$ and $944 \pm 65 \mathrm{mg}$, 
respectively (Figure 1). Ghrelin given at a dose of $12.5 \mu \mathrm{g} / \mathrm{kg}$ was without a significant effect on pancreatic weight in sensory nerves-intact rats infused subcutaneously with cerulein.

Capsaicin deactivation of sensory nerves (CDSN) tended to enhance the cerulein-evoked increase in pancreatic edema and pancreatic weight. However, the difference between pancreatic weight in sensory nerves-intact rats treated with saline before cerulein infusion and rats with CDSN treated with saline before cerulein infusion was not statistically significant.

CDSN abolished the ghrelin-induced reduction in cerulein-evoked increase in pancreatic weight. In rats with CDSN pretreated with ghrelin prior to the development of cerulein-induced pancreatitis (CIP), pancreatic weight reached a value of $2050 \pm 150 \mathrm{mg}$ and was even slightly increased in comparison to pancreatic weight observed in sensory nerves-intact rats without pretreatment with ghrelin before induction of acute pancreatitis or rats with CDSN pretreated with saline before CIP. Pancreatic weight in rats with CDSN treated with ghrelin given at a dose of $50 \mu \mathrm{g} / \mathrm{kg}$ before induction of CIP was significantly higher than that observed in sensory nerves-intact rats pretreated with the same dose of ghrelin before CIP development.

Administration of ghrelin at a dose of $50 \mu \mathrm{g} / \mathrm{kg}$ did not alter pancreatic weight in rats with CDSN without CIP (Figure 1).

Pancreases, obtained from control sensory nerves-intact rats treated with saline without CIP, were characterized by normal morphology in both, macro- and microscopic evaluation (Figures 2 and 3, Table 1). In sensory nerves-intact rats without induction of CIP, administration of ghrelin at doses used failed to affect morphology of the pancreas (Figure 3, Table 1).

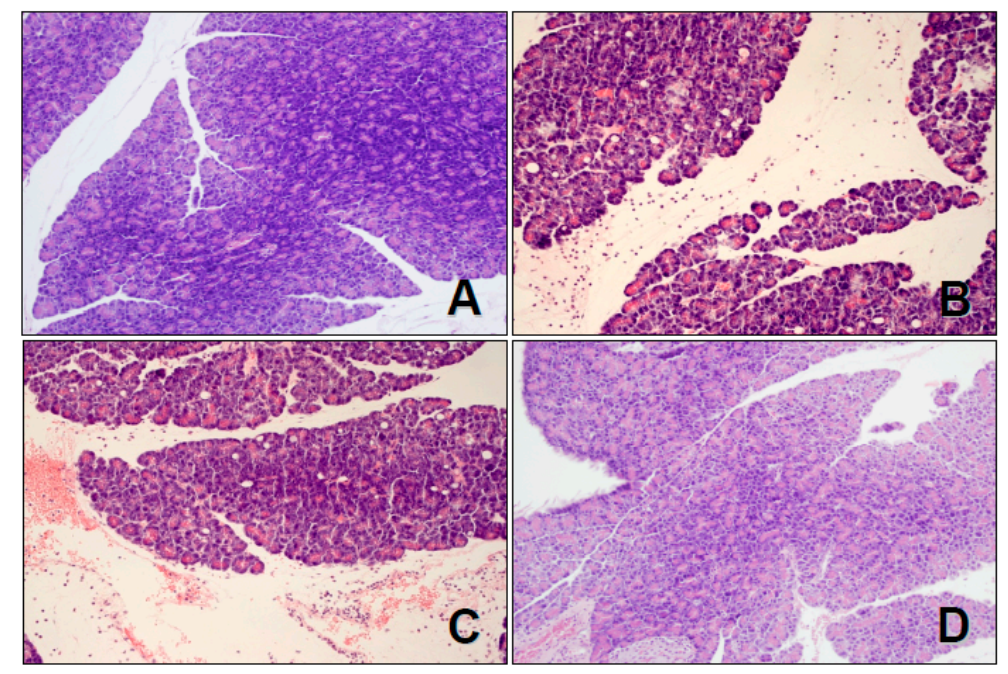

Figure 2. Histological images of pancreatic tissues stained with hematoxylin and eosin, magnification $400 \times$ : (A) control sensory nerves-intact rats treated with saline without cerulein-induced pancreatitis (CIP); (B) sensory nerves-intact rats treated with saline followed by CIP development; (C) rats with capsaicin deactivation of sensory nerves treated with saline followed by CIP development; and (D) Sensory nerves-intact rats treated with ghrelin given at a dose of $50 \mu \mathrm{g} / \mathrm{kg}$ followed by CIP development.

In sensory nerves-intact rats pretreated with saline, infusion with cerulein led to the development of acute pancreatitis. Macroscopically it was manifested as a marked swelling of the pancreas. Microscopic evaluation revealed pancreatic interlobular edema and moderate or severe intralobular edema accompanied by moderate perivascular and scarce diffuse inflammatory infiltration or abundant diffuse inflammatory infiltration. In most cases, vacuolization was observed in more than $50 \%$ of acinar cells. No necrosis or hemorrhage was observed. In these groups of rats, total histological score reached a value of $7.60 \pm 0.27$ (Figure 3). In rats with intact sensory nerves, administration of ghrelin before generation of CIP led to reduction in morphological signs of acute pancreatitis, as compared to sensory nerves-intact rats treated with saline before induction of CIP (Figures 2 and 3, Table 1). 


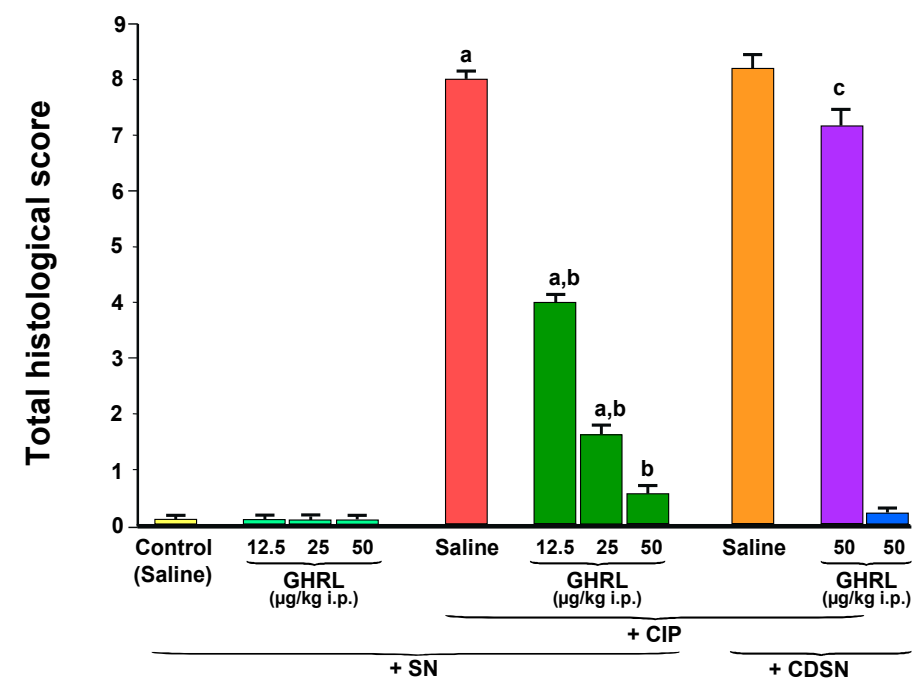

Figure 3. Effect of saline or ghrelin (GHRL) given intraperitoneally at a dose of $12.5,25 \mathrm{or} 50 \mu \mathrm{g} / \mathrm{kg}$ and cerulein-induced pancreatitis (CIP) on total histological score in sensory nerves-intact rats (SN) or rats with capsaicin deactivation of sensory nerves (CDSN). ${ }^{\mathrm{a}} p<0.05$ compared to the control group with intact sensory nerves and without induction of CIP; ${ }^{b} p<0.05$ compared to sensory nerves-intact rats with CIP pretreated with saline; ${ }^{c} p<0.05$ compared to sensory nerves-intact rats pretreated with GHRL at a dose of $50 \mu \mathrm{g} / \mathrm{kg}$ prior to CIP. Mean \pm SEM from values obtained from 10-15 rats in each experimental group.

Table 1. Effect of saline or ghrelin (GHRL) given intraperitoneally at increasing doses of $12.5,25$ or $50 \mu \mathrm{g} / \mathrm{kg}$ on morphological changes of pancreatic tissues in the course of cerulein-induced pancreatitis (CIP) in animals with intact sensory nerves or with capsaicin deactivation of sensory nerves.

\begin{tabular}{|c|c|c|c|}
\hline Groups & Edema (0-3) & Infiltration (0-3) & Vacuolization (0-3) \\
\hline \multicolumn{4}{|c|}{ Intact Sensory Nerves } \\
\hline Control (saline) & 0 & 0 & 0 \\
\hline $\mathrm{CIP}$ & $2-3$ & $2-3$ & 3 \\
\hline GHRL $12.5 \mu \mathrm{g} / \mathrm{kg}$ & 0 & 0 & 0 \\
\hline GHRL $25 \mu \mathrm{g} / \mathrm{kg}$ & 0 & 0 & 0 \\
\hline GHRL $50 \mu \mathrm{g} / \mathrm{kg}$ & 0 & 0 & 0 \\
\hline GHRL $12.5 \mu \mathrm{g} / \mathrm{kg}+\mathrm{CIP}$ & $2-3$ & 2 & $2-3$ \\
\hline GHRL $25 \mu \mathrm{g} / \mathrm{kg}+\mathrm{CIP}$ & 2 & $1-2$ & $2-3$ \\
\hline GHRL $50 \mu \mathrm{g} / \mathrm{kg}+\mathrm{CIP}$ & $1-2$ & $1-2$ & 2 \\
\hline \multicolumn{4}{|c|}{ Capsaicin Deactivation of Sensory Nerves } \\
\hline Saline & 0 & 0 & 0 \\
\hline CIP & $2-3$ & $2-3$ & 3 \\
\hline GHRL $50 \mu \mathrm{g} / \mathrm{kg}+\mathrm{CIP}$ & 3 & $2-3$ & 3 \\
\hline GHRL $50 \mu \mathrm{g} / \mathrm{kg}$ & 0 & 0 & 0 \\
\hline
\end{tabular}

Numbers represent the predominant histological grading in each experimental group.

CDSN performed prior to induction of CIP tended to increase the severity of acute pancreatitis in comparison to findings observed in sensory nerves-intact rats with development of CIP, but this effect was statistically insignificant (Figures 2 and 3, Table 1).

The usage of ghrelin, at a selected dose of $50 \mu \mathrm{g} / \mathrm{kg}$, prior to the start of cerulein infusion in the group of animals with CDSN, failed to improve the morphology of the pancreas. Morphological signs of pancreatic damage in this group of animals were significantly bigger than that observed in sensory nerves-intact rats treated with ghrelin at a dose of $50 \mu \mathrm{g} / \mathrm{kg}$ before induction of CIP. 
The use of ghrelin without induction of CIP did not affected pancreatic morphology in rats with intact sensory nerves or rats with CDSN (Figure 3, Table 1).

\subsubsection{Plasma Lipase Activity}

Plasma lipase activity in control sensory nerves-intact rats treated with saline without induction of CIP was $100 \pm 15 \mathrm{IU} / \mathrm{L}$ and remained unchanged following administration of increasing doses of ghrelin, 12.5, 25 or $50 \mu \mathrm{g} / \mathrm{kg}$ (Figure 4).

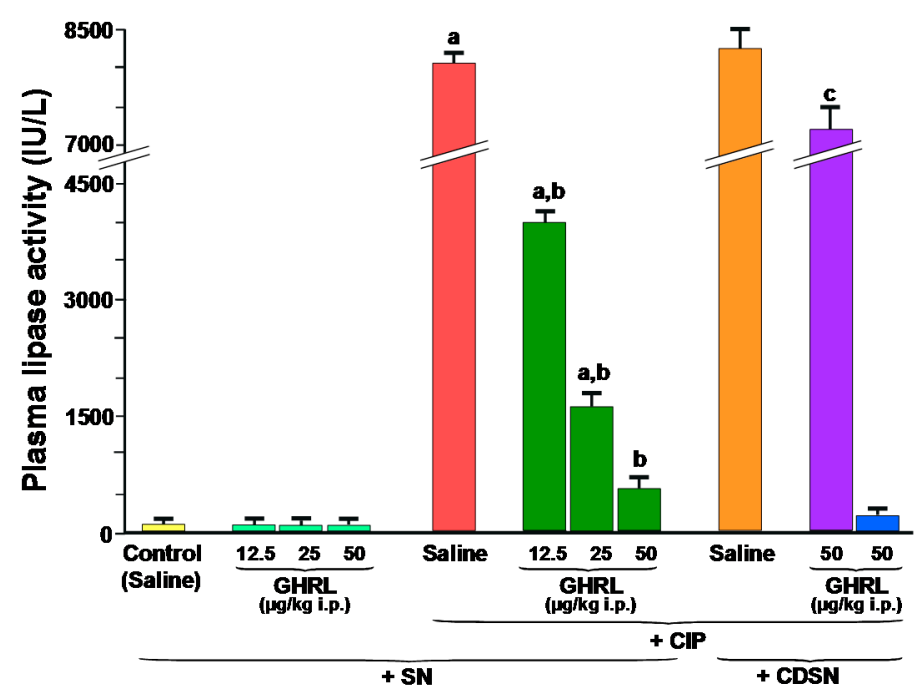

Figure 4. Effect of saline or ghrelin (GHRL) given intraperitoneally at a dose of $12.5,25$ or $50 \mu \mathrm{g} / \mathrm{kg}$ and cerulein-induced pancreatitis (CIP) on plasma activity of lipase in sensory nerves-intact rats (SN) or rats with capsaicin deactivation of sensory nerves (CDSN). ${ }^{a} p<0.05$ compared to the control group with intact sensory nerves and without induction of CIP; $p<0.05$ compared to sensory nerves-intact rats with CIP pretreated with saline; ${ }^{\mathrm{C}} p<0.05$ compared to sensory nerves-intact rats pretreated with GHRL at a dose of $50 \mu \mathrm{g} / \mathrm{kg}$ prior to CIP. Mean \pm SEM from values obtained from 10-15 rats in each experimental group.

In sensory nerves-intact rats, induction of acute pancreatitis by cerulein caused a dramatic, statistically significant increase in plasma activity of lipase to around $8000 \mathrm{IU} / \mathrm{L}$. In rats with intact sensory nerves, administration of ghrelin at increasing doses, $12.5,25 \mathrm{or} 50 \mu \mathrm{g} / \mathrm{kg}$ before the induction of CIP, resulted in a statistically significant decrease in plasma activity of this pancreatic digestive enzyme to approximately 4000, 1600 and $650 \mathrm{IU} / \mathrm{L}$, respectively (Figure 4).

CDSN tended to increase plasma activity of lipase in rats with CIP, but this effect was statistically insignificant. Administration of ghrelin at a dose of $50 \mu \mathrm{g} / \mathrm{kg}$ before the start of cerulein infusion was without significant effect on plasma activity of lipase in rats with CDSN and CIP.

In addition, administration of ghrelin did not affect plasma activity of lipase in rats with CDSN, but without induction of CIP (Figure 4).

\subsubsection{Pancreatic Blood Flow}

Intraperitoneal administration of increasing doses of ghrelin, 12.5, $25 \mathrm{or} 50 \mu \mathrm{g} / \mathrm{kg}$, did not affect pancreatic blood flow in sensory nerves-intact rats without induction of acute pancreatitis (Figure 5).

In sensory nerves-intact rats, the development of CIP significantly reduced pancreatic blood flow by about $40 \%$. Pretreatment with ghrelin at doses used, $30 \mathrm{~min}$ before the start of cerulein infusion, failed to significantly affect pancreatic blood flow in sensory nerves-intact rats or rats with CDSN. CDSN in rats pretreated with saline before CIP tended to further decrease in pancreatic blood flow, but this effect was statistically insignificant. On the other hand, we found a significant difference 
in pancreatic blood flow between two groups of rats without CIP: rats with intact sensory nerves treated with ghrelin given at a dose of $50 \mu \mathrm{g} / \mathrm{kg}$ and rats with CDSN treated with the same dose of this polypeptide. CDSN reduced pancreatic blood flow by almost 30\% (Figure 5).

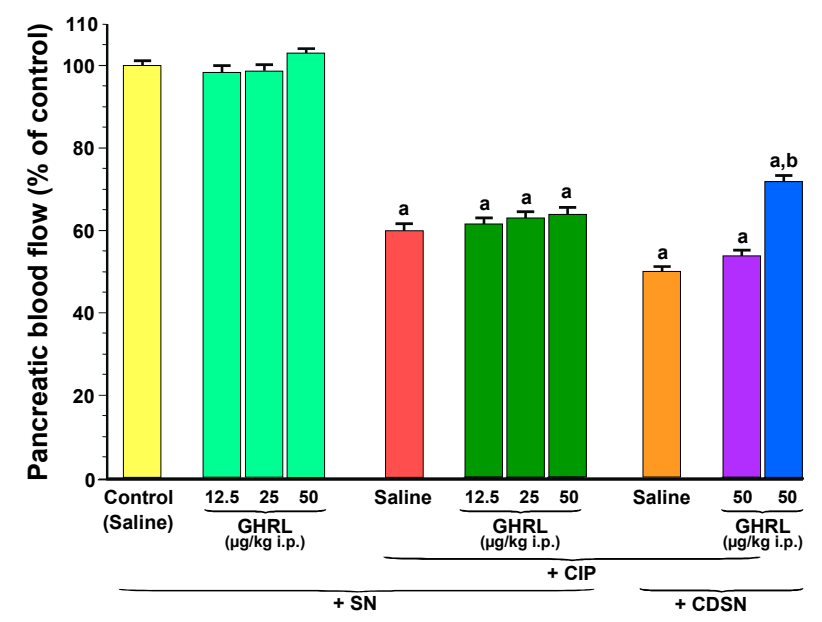

Figure 5. Effect of saline or ghrelin (GHRL) given intraperitoneally at a dose of 12.5, 25 or $50 \mu \mathrm{g} / \mathrm{kg}$ and cerulein-induced pancreatitis (CIP) on pancreatic blood flow in sensory nerves-intact rats (SN) or rats with capsaicin deactivation of sensory nerves (CDSN). ${ }^{a} p<0.05$ compared to the control group with intact sensory nerves and without induction of $\mathrm{CIP} ;{ }^{b} p<0.05$ compared to sensory nerves-intact rats pretreated with GHRL at a dose of $50 \mu \mathrm{g} / \mathrm{kg}$ without induction of CIP. Mean \pm SEM from values obtained from 10-15 rats in each experimental group.

\subsubsection{Plasma Concentration of Tumor Necrosis Factor- $\alpha$ (TNF- $\alpha$ ) and Interleukin- 4}

Plasma concentration of the pro-inflammatory cytokine, TNF- $\alpha$ in the control group of animals with intact sensory nerves and treated with saline was $5.1 \pm 0.5 \mathrm{pg} / \mathrm{mL}$ and remained unchanged following treatment with increasing doses of ghrelin, 12.5, 25 or $50 \mu \mathrm{g} / \mathrm{kg}$ (Figure 6).

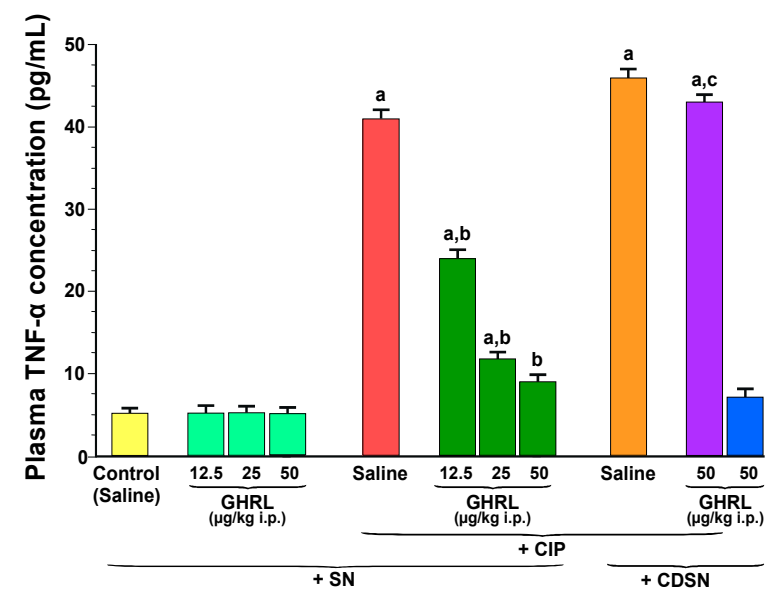

Figure 6. Effect of saline or ghrelin (GHRL) given intraperitoneally at a dose of $12.5,25 \mathrm{or} 50 \mu \mathrm{g} / \mathrm{kg}$ and cerulein-induced pancreatitis (CIP) on plasma concentration of tumor necrosis factor- $\alpha$ (TNF- $\alpha$ ) in sensory nerves-intact rats (SN) or rats with capsaicin deactivation of sensory nerves (CDSN). a $p<0.05$ compared to the control group with intact sensory nerves and without induction of CIP;

${ }^{\mathrm{b}} p<0.05$ compared to sensory nerves-intact rats with CIP pretreated with saline; ${ }^{\mathrm{c}} p<0.05$ compared to sensory nerves-intact rats pretreated with GHRL at a dose of $50 \mu \mathrm{g} / \mathrm{kg}$ prior to CIP. Mean $\pm \mathrm{SEM}$ from values obtained from 10-15 rats in each experimental group. 
CIP resulted in a statistically significant increase in the concentration of TNF- $\alpha$ up to $41.0 \pm 7.0 \mathrm{pg} / \mathrm{mL}$. Increasing doses of ghrelin, $12.5,25 \mathrm{or} 50 \mu \mathrm{g} / \mathrm{kg}$ given intraperitoneally $30 \mathrm{~min}$ prior to the induction of CIP, resulted in a statistically significant reduction in plasma concentration of TNF- $\alpha$ to the level of $24.0 \pm 2.5,11.8 \pm 1.5$, and $9.0 \pm 1.0 \mathrm{pg} / \mathrm{mL}$, respectively (Figure 6).

In rats with CDSN treated with saline before induction of CIP, plasma concentration of TNF- $\alpha$ reached a value of $46.0 \pm 8.0 \mathrm{pg} / \mathrm{mL}$. This concentration of TNF- $\alpha$ was higher than that observed in sensory nerves-intact rats treated with saline before induction of CIP, but this difference was statistically insignificant. In rats with CDSN, administration of ghrelin at a dose of $50 \mu \mathrm{g} / \mathrm{kg}$ prior to start of cerulein infusion did not significantly affect plasma level of TNF- $\alpha$. For this reason, there was a statistically significant difference in plasma level of TNF- $\alpha$ between sensory nerves-intact rats pretreated with ghrelin at a dose of $50 \mu \mathrm{g} / \mathrm{kg}$ before induction of CIP and rats with CDSN pretreated with the same dose of ghrelin before induction of CIP. Pretreatment with ghrelin was without effect on plasma concentration of TNF- $\alpha$ in rats with CDSN without CIP (Figure 6).

Plasma concentration of anti-inflammatory cytokine, interleukin-4 in control, sensory nerves-intact rats treated with saline without CIP was $185 \pm 20 \mathrm{pg} / \mathrm{mL}$ and remained unchanged after administration of ghrelin at doses used (Figure 7).

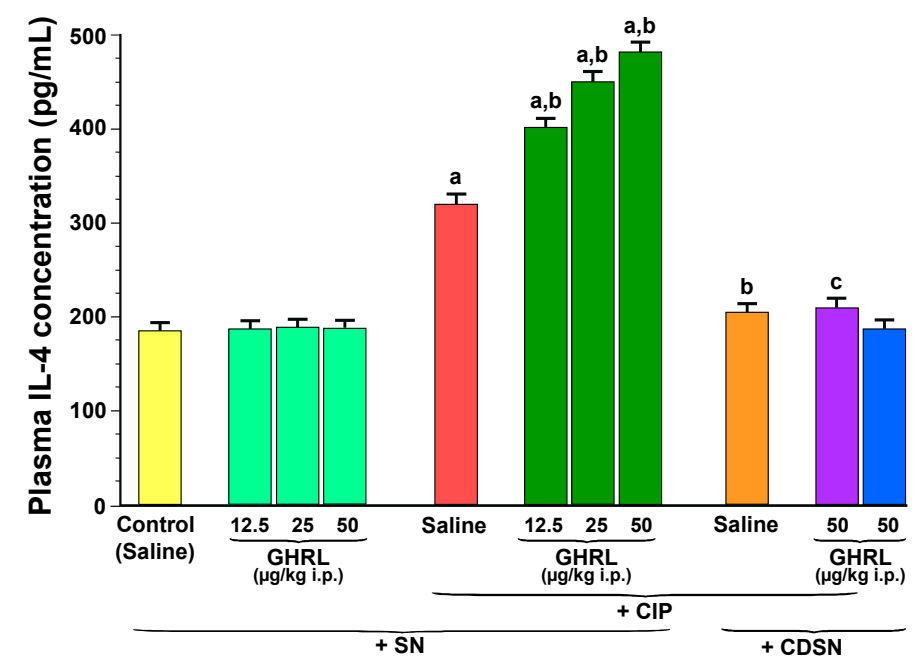

Figure 7. Effect of saline or ghrelin (GHRL) given intraperitoneally at a dose of $12.5,25 \mathrm{or} 50 \mu \mathrm{g} / \mathrm{kg}$ and cerulein-induced pancreatitis (CIP) on plasma concentration of interleukin-4 (IL-4) in sensory nerves-intact rats $(\mathrm{SN})$ or rats with capsaicin deactivation of sensory nerves (CDSN). ${ }^{\mathrm{a}} p<0.05$ compared to the control group with intact sensory nerves and without induction of CIP; ${ }^{b} p<0.05$ compared to sensory nerves-intact rats with CIP pretreated with saline; ${ }^{\mathrm{c}} p<0.05$ compared to sensory nerves-intact rats pretreated with GHRL at a dose of $50 \mu \mathrm{g} / \mathrm{kg}$ prior to CIP. Mean \pm SEM from values obtained from 10-15 rats in each experimental group.

CIP resulted in a statistically significant increase in the concentration of interleukin-4 to $320 \pm 25 \mathrm{pg} / \mathrm{mL}$ in rats with intact sensory nerves. Administration of ghrelin at a dose of $12.5,25$ or $50 \mu \mathrm{g} / \mathrm{kg}$ before the induction of CIP, led to an additional and statistically significant increase in plasma interleukin- 4 concentration to a level of $410 \pm 50,450 \pm 55$ and $482 \pm 60 \mathrm{pg} / \mathrm{mL}$, respectively (Figure 7).

In contrast to effects observed in sensory nerves-intact rats, capsaicin deactivation of sensory nerves abolished the CIP-evoked increase in plasma level of interleukin-4 in rats pretreated with saline, as well as the stimulatory effect on the release of this anti-inflammatory cytokine evoked by the combination of ghrelin plus CIP. Administration of ghrelin was also without any effect on plasma concentration of interleukin-4 in rats with CDSN without induction of acute pancreatitis (Figure 7). 


\subsection{In Vitro Studies Performed on Isolated Pancreatic Acinar Cells Obtained from Rats with Intact or Deactivated Sensory Nerves}

\subsubsection{Determination of TNF- $\alpha$ Gene Expression and Protein Synthesis}

The gene expression of pro-inflammatory cytokine, TNF- $\alpha$ in isolated rat pancreatic acinar cells in the in vitro model was detected in all samples tested. In acinar cells, obtained from control sensory nerves-intact rats treated with saline and after isolation incubated in cerulein-free solution, the ratio of TNF- $\alpha / \beta$-actin mRNA signal was $0.20 \pm 0.02$ (Figure 8). Intraperitoneal administration of ghrelin before isolation of acinar cells from rats with intact sensory nerves did not significantly alter the ratio of TNF- $\alpha / \beta$-actin gene expression in comparison to control group ( $0.24 \pm 0.02$ versus $0.20 \pm 0.02)$.
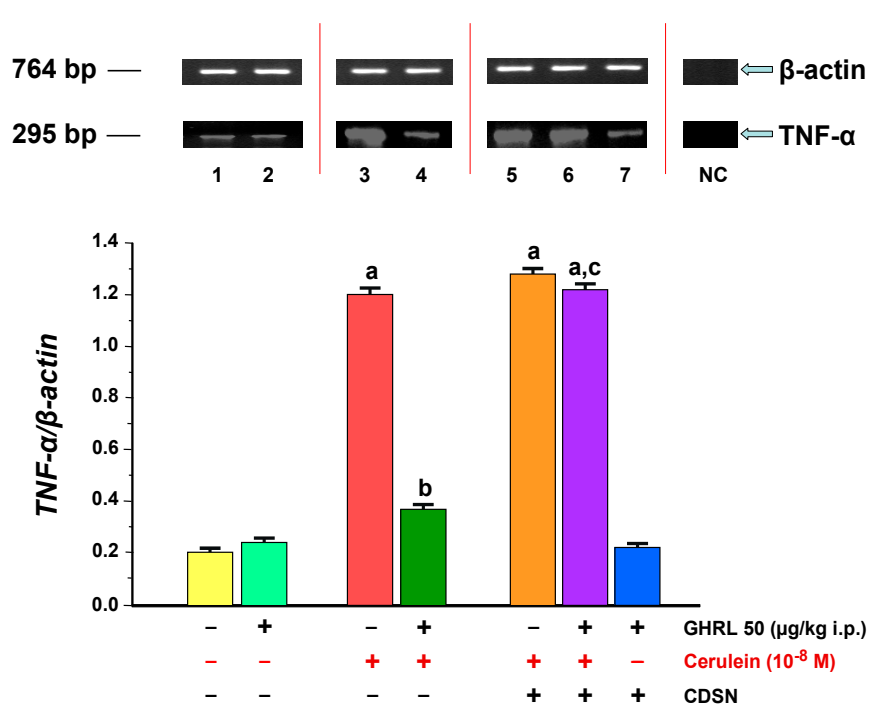

Figure 8. Analysis of tumor necrosis factor- $\alpha$ (TNF- $\alpha)$ gene expression assessed using reverse transcription-polymerase chain reaction (RT-PCR) and densitometric analysis of TNF- $\alpha / \beta$-actin mRNA ratio in isolated pancreatic acinar cells: (lane 1) acinar cells obtained from control sensory nerves (SN)-intact rats treated with saline, after isolation, acinar cells incubated in cerulein-free solution; (lane 2) acinar cells obtained from SN-intact rats treated with ghrelin (GHRL), after isolation, acinar cells incubated in cerulein-free solution; (lane 3) acinar cells obtained from SN-intact rats treated with saline, after isolation, acinar cells incubated in solution containing cerulein at a concentration of $10^{-8} \mathrm{M}$; (lane 4) acinar cells obtained from SN-intact rats treated with GHRL, after isolation, acinar cells incubated in solution containing cerulein at a concentration of $10^{-8} \mathrm{M}$; (lane 5) acinar cells obtained from rats with capsaicin deactivation of SN (CDSN) and treated with saline, after isolation, acinar cells incubated in solution containing cerulein at a concentration of $10^{-8} \mathrm{M}$; (lane 6) acinar cells obtained from rats with CDSN and treated with GHRL, after isolation, acinar cells incubated in solution containing cerulein at a concentration of $10^{-8} \mathrm{M}$; (lane 7) acinar cells obtained from rats with CDSN and treated with GHRL, after isolation, acinar cells incubated in cerulein-free solution. $\mathrm{NC}=$ negative control. Reference gene: $\beta$-actin. ${ }^{a} p<0.05$ compared to control acinar cells obtained from rats with intact SN (lane 1); ${ }^{\mathrm{b}} p<0.05$ compared to acinar cells stimulated with cerulein after isolation from $\mathrm{SN}$-intact rats treated with saline (line 3); ${ }^{\mathrm{c}} p<0.05$ compared to acinar cells stimulated with cerulein after isolation from SN-intact rats treated with GHRL (lane 4). In each experimental group, there was at least six observations.

Hyperstimulation of pancreatic acinar cells with cerulein given at a concentration of $10^{-8} \mathrm{M}$ resulted in a statistically significant increase in TNF- $\alpha$ gene expression, the ratio of mRNA for TNF- $\alpha$ to mRNA for $\beta$-actin reached a level of $1.20 \pm 0.06$. Peripheral administration of ghrelin, before isolation of acinar cells from sensory intact rats, and incubation of those acinar cells with cerulein resulted in 
a statistically significant decrease in expression of mRNA for TNF- $\alpha$. The ratio of TNF- $\alpha / \beta$-actin mRNA was $0.37 \pm 0.03$ (Figure 8).

CDSN performed before treatment with ghrelin, abolished the inhibitory effect of ghrelin on $T N F-\alpha$ gene expression in isolated acinar cells stimulated with cerulein. Comparison of gene expression for TNF- $\alpha$ in pancreatic acinar cells obtained from rats with intact sensory nerves treated with ghrelin and rats with CDSN treated with ghrelin showed no difference between them (Figure 8).

The presence of the pro-inflammatory cytokine, TNF- $\alpha$ protein has been demonstrated in isolated pancreatic acinar cells in the in vitro model in all animal groups (Figure 9). The ratio value calculated for TNF- $\alpha$ /GAPDH (Glyceraldehyde-3-Phosphate Dehydrogenase) protein synthesis in isolated acinar cells incubated in cerulein-free solution and obtained from control sensory nerves-intact rats treated with saline was $0.098 \pm 0.004$. Peripheral administration of ghrelin to rats with intact sensory nerves prior to the in vitro experiment, did not significantly affect the ratio of TNF- $\alpha$ /GAPDH protein, which remained at the level of $0.11 \pm 0.01$ (Figure 9).

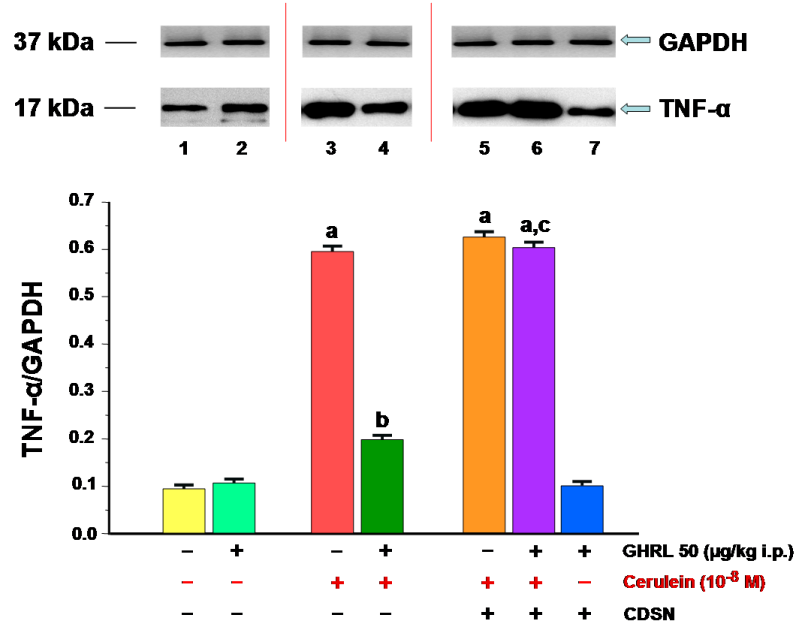

Figure 9. Analysis of tumor necrosis factor- $\alpha$ (TNF- $\alpha)$ protein synthesis determined by the method of immunoblotting and densitometric analysis of TNF- $\alpha$ /glyceraldehyde-3-phosphate dehydrogenase (GAPDH) protein ratio in isolated pancreatic acinar cells: (lane 1) acinar cells obtained from control sensory nerves (SN)-intact rats treated with saline, after isolation, acinar cells incubated in cerulein-free solution; (lane 2) acinar cells obtained from SN-intact rats treated with ghrelin (GHRL), after isolation, acinar cells incubated in cerulein-free solution; (lane 3) acinar cells obtained from SN-intact rats treated with saline, after isolation, acinar cells incubated in solution containing cerulein at a concentration of $10^{-8} \mathrm{M}$; (lane 4) acinar cells obtained from SN-intact rats treated with GHRL, after isolation, acinar cells incubated in solution containing cerulein at a concentration of $10^{-8} \mathrm{M}$; (lane 5) acinar cells obtained from rats with capsaicin deactivation of SN (CDSN) and treated with saline, after isolation, acinar cells incubated in solution containing cerulein at a concentration of $10^{-8} \mathrm{M}$; (lane 6) acinar cells obtained from rats with CDSN and treated with GHRL, after isolation, acinar cells incubated in solution containing cerulein at a concentration of $10^{-8} \mathrm{M}$; (lane 7) acinar cells obtained from rats with CDSN and treated with GHRL, after isolation, acinar cells incubated in cerulein-free solution. ${ }^{\text {a }} p<0.05$ compared to control acinar cells obtained from rats with intact SN (lane 1); ${ }^{b} p<0.05$ compared to acinar cells stimulated with cerulein after isolation from SN-intact rats treated with saline (line 3); ${ }^{\mathrm{c}} p<0.05$ compared to acinar cells stimulated with cerulein after isolation from SN-intact rats treated with GHRL (lane 4). In each experimental group, there was at least six observations.

The stimulation of isolated pancreatic acinar cells with cerulein, given at a supramaximal, previously selected concentration of $10^{-8} \mathrm{M}$ for $5 \mathrm{~h}$, resulted in a statistically significant in increase synthesis of TNF- $\alpha$ protein. This effect reached a similar value in acinar cells obtained from sensory 
nerves-intact rats treated with saline and rats with CDSN and treated with saline. The ratio of TNF- $\alpha$ protein/GAPDH protein was in those cells $0.59 \pm 0.05$ and $0.63 \pm 0.06$, respectively (Figure 9).

Intraperitoneal administration of ghrelin, before isolation of pancreatic acinar cells, in rats with intact sensory nerves significantly reversed the cerulein-induced increase in synthesis of TNF- $\alpha$ in those cells. The ratio of TNF- $\alpha$ protein to GAPDH protein reached a value $0.20 \pm 0.02$ (Figure 9). In contrast, the cerulein-induced increase in TNF- $\alpha$ synthesis was not affected by pretreatment with ghrelin in acinar cells obtained from rats with CDSN.

CDSN failed to affect synthesis of TNF- $\alpha$ in acinar cells incubated in cerulein-free medium after isolation from rats pretreated with ghrelin. The ratio TNF- $\alpha /$ GAPDH in those cells reached a value of $0.10 \pm 0.01$ and was similar to that observed in acinar cells isolated from sensory nerves-intact rats pretreated with ghrelin and after isolation, incubated in cerulein-free medium (Figure 9).

\subsubsection{Determination of Heat Shock Protein 70 (HSP70) Gene Expression and Protein Synthesis}

The presence of HSP70 mRNA signal was demonstrated in vitro in isolated pancreatic acinar cells obtained from all experimental groups. In pancreatic cells obtained from sensory nerves-intact rats pretreated with saline (control group), the ratio of HSP70/ $\beta$-actin gene expression was $0.05 \pm 0.001$. Peritoneal application of ghrelin to rats $48 \mathrm{~h}$ prior to in vitro experiment, led to a statistically significant increase the ratio of HSP70/ $\beta$-actin gene expression to the level of $0.60 \pm 0.03$ (Figure 10).

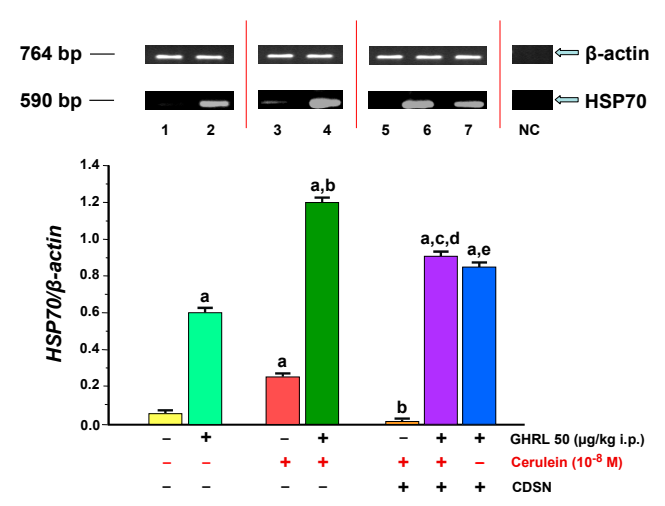

Figure 10. Analysis of heat shock protein 70 (HSP70) gene expression assessed using RT-PCR and densitometric analysis of HSP70/ $\beta$-actin mRNA ratio in isolated pancreatic acinar cells: (lane 1) acinar cells obtained from control sensory nerves (SN)-intact rats treated with saline, after isolation, acinar cells incubated in cerulein-free solution; (lane 2) acinar cells obtained from SN-intact rats treated with ghrelin (GHRL), after isolation, acinar cells incubated in cerulein-free solution; (lane 3) acinar cells obtained from $\mathrm{SN}$-intact rats treated with saline, after isolation, acinar cells incubated in solution containing cerulein at a concentration of $10^{-8} \mathrm{M}$; (lane 4) acinar cells obtained from SN-intact rats treated with GHRL, after isolation, acinar cells incubated in solution containing cerulein at a concentration of $10^{-8} \mathrm{M}$; (lane 5) acinar cells obtained from rats with capsaicin deactivation of SN (CDSN) and treated with saline, after isolation, acinar cells incubated in solution containing cerulein at a concentration of $10^{-8} \mathrm{M}$; (lane 6) acinar cells obtained from rats with CDSN and treated with GHRL, after isolation, acinar cells incubated in solution containing cerulein at a concentration of $10^{-8} \mathrm{M}$; (lane 7) acinar cells obtained from rats with CDSN and treated with GHRL, after isolation, acinar cells incubated in cerulein-free solution. $\mathrm{NC}=$ negative control. Reference gene: $\beta$-actin. ${ }^{\mathrm{a}} p<0.05$ compared to control acinar cells obtained from rats with intact SN (lane 1$) ;{ }^{b} p<0.05$ compared to acinar cells stimulated with cerulein after isolation from SN-intact rats treated with saline (line 3); ${ }^{\mathrm{c}} p<0.05$ compared to acinar cells stimulated with cerulein after isolation from rats with CDSN and treated with saline (lane 5); ${ }^{\mathrm{d}} p<0.05$ compared to acinar cells stimulated with cerulein after isolation from $\mathrm{SN}$-intact rats treated with GHRL (lane 4); ${ }^{\mathrm{e}} p<0.05$ compared to acinar cells incubated in cerulein-free solution after isolation from SN-intact rats treated with GHRL (lane 2). In each experimental group, there was at least six observations. 
Stimulation of rat pancreatic acinar cells with a selected supramaximal concentration of cerulein, $10^{-8} \mathrm{M}$ for $5 \mathrm{~h}$, resulted in a statistically significant increase in the ratio HSP70/ $\beta$-actin mRNA to the level of $0.25 \pm 0.01$. In the in vivo model, intraperitoneal administration of ghrelin to rats, at a dose of $50 \mu \mathrm{g} / \mathrm{kg}$, $48 \mathrm{~h}$ before the use of the pancreatic secretagogue in vitro, resulted in a statistically significant increase in a value ratio of HSP70/ $\beta$-actin mRNA to $1.20 \pm 0.06$ (Figure 10).

CDSN before isolation of acinar cells from rats treated with saline produced a significant decrease in the ratio of HSP70/ $\beta$-actin mRNA in pancreatic acinar cells stimulated with cerulein in comparison to a value observed in acinar cells obtained from sensory nerves-intact rats treated with saline $(0.01 \pm 0.001$ versus $1.20 \pm 0.06)$.

Intraperitoneal administration of ghrelin to animals with CDSN in vivo prior to the administration of cerulein at a concentration of $10^{-8} \mathrm{M}$ in vitro, resulted in a statistically significant increase in the ratio values of HSP70/ $\beta$-actin mRNA signal in comparison to the group without administration of ghrelin. However, this ratio was still significantly lower than that observed in acinar cells incubated with cerulein after isolation from sensory intact-rats treated with ghrelin (0.91 \pm 0.04 versus $1.20 \pm 0.06)$. On the other hand, the ratio HSP70/ $\beta$-actin mRNA is significantly lower in acinar cells incubated in cerulein-free solution after isolation from sensory nerves-intact rats treated with ghrelin than that observed in acinar cells incubated in cerulein-free solution after isolation from rats with CDSN and treated with ghrelin $(0.60 \pm 0.03$ versus $0.85 \pm 0.04)$ (Figure 10).

In the rat isolated pancreatic acinar cells in the in vitro model, the presence of HSP70 was detected in all studied groups (Figure 11). The ratio of HSP70/GAPDH protein in the control group (acinar cells obtained from sensory nerves-intact rats treated with saline, after isolation, acinar cells incubated in cerulein-free solution) was $0.01 \pm 0.001$. Peripheral administration of ghrelin to sensory nerves-intact rats prior to in vitro experiment, resulted in a statistically significant increase the ratio value to $0.15 \pm 0.01$.

Stimulation of pancreatic acinar cells via pancreatic secretagogue, cerulein given at a concentration of $10^{-8} \mathrm{M}$ for $5 \mathrm{~h}$ led to a statistically significant increase in cellular synthesis of HSP70 to a level of $0.06 \pm 0.003$ compared to HSP70 production observed in control acinar cells incubated in cerulein-free solution. In vivo administration of ghrelin prior to cerulein usage in vitro resulted in a statistically significant increase in the ratio of HSP70/GAPDH protein to a value of $0.28 \pm 0.02$ (Figure 11).

CDSN caused a dramatic, statistically significant decrease in ratio of HSP70 to GAPDH in the pancreatic acinar cells stimulated by cerulein, at a concentration of $10^{-8} \mathrm{M}$, to the level of $0.003 \pm 0.0001$, as compared to acinar cells incubated in cerulein containing solution and obtained from sensory nerves-intact rats. In rats with CDSN, intraperitoneal administration of ghrelin in vivo at a dose of $50.0 \mu \mathrm{g} / \mathrm{kg}, 48 \mathrm{~h}$ prior to the in vitro incubation in cerulein containing solution $\left(10^{-8} \mathrm{M}\right)$, resulted in a statistically significant increase of the ratio of HSP70 protein to GAPDH protein to the value of $0.20 \pm 0.02$ versus the groups without treatment with ghrelin. However, it still remained significantly smaller compared to ratio observed in acinar cells obtained from sensory nerves-intact animals receiving ghrelin at the same dose, followed by incubation of acinar cells in cerulein containing solution $(0.28 \pm 0.02)$. On the other hand, the ratio of HSP70/GAPDH protein signals in pancreatic acinar cells incubated in cerulein-free solution after isolation from animals with CDSN and treated with ghrelin was significantly higher than that ratio observed in pancreatic acinar cells incubated in cerulein-free solution after isolation from rats with intact sensory nerves and treated with ghrelin $(0.18 \pm 0.01$ versus $0.15 \pm 0.01)$ (Figure 11). 


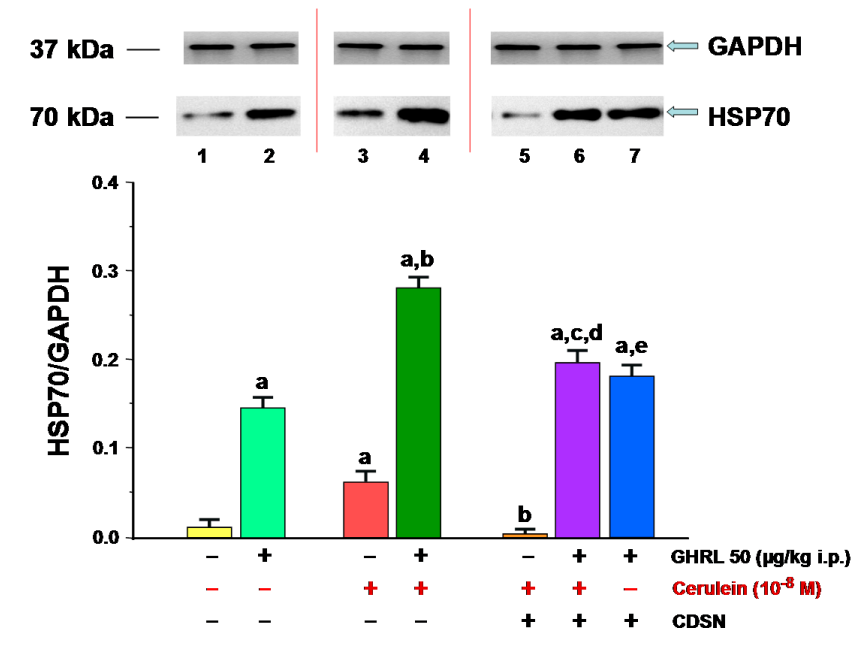

Figure 11. Analysis of the HSP70 protein synthesis determined by the method of immunoblotting and densitometric analysis of TNF- $\alpha$ /GAPDH protein ratio in isolated pancreatic acinar cells : (lane 1) acinar cells obtained from control sensory nerves (SN)-intact rats treated with saline, after isolation, acinar cells incubated in cerulein-free solution; (lane 2) acinar cells obtained from SN-intact rats treated with ghrelin (GHRL), after isolation, acinar cells incubated in cerulein-free solution; (lane 3) acinar cells obtained from $\mathrm{SN}$-intact rats treated with saline, after isolation, acinar cells incubated in solution containing cerulein at a concentration of $10^{-8} \mathrm{M}$; (lane 4) acinar cells obtained from SN-intact rats treated with GHRL, after isolation, acinar cells incubated in solution containing cerulein at a concentration of $10^{-8} \mathrm{M}$; (lane 5) acinar cells obtained from rats with capsaicin deactivation of SN (CDSN) and treated with saline, after isolation, acinar cells incubated in solution containing cerulein at a concentration of $10^{-8} \mathrm{M}$; (lane 6) acinar cells obtained from rats with CDSN and treated with GHRL, after isolation, acinar cells incubated in solution containing cerulein at a concentration of $10^{-8} \mathrm{M}$; (lane 7) acinar cells obtained from rats with CDSN and treated with GHRL, after isolation, acinar cells incubated in cerulein-free solution. ${ }^{\mathrm{a}} p<0.05$ compared to control acinar cells obtained from rats with intact SN (lane 1); ${ }^{\mathrm{b}} p<0.05$ compared to acinar cells stimulated with cerulein after isolation from SN-intact rats treated with saline (line 3); ${ }^{\mathrm{c}} p<0.05$ compared to acinar cells stimulated with cerulein after isolation from rats with CDSN and treated with saline (lane 5); ${ }^{\mathrm{d}} p<0.05$ compared to acinar cells stimulated with cerulein after isolation from SN-intact rats treated with GHRL (lane 4); ${ }^{\mathrm{e}} p<0.05$ compared to acinar cells incubated in cerulein-free solution after isolation from SN-intact rats treated with GHRL (lane 2). In each experimental group, there was at least six observations.

\section{Discussion}

Previous studies showed that pretreatment with ghrelin inhibits the development of acute pancreatitis evoked by cerulein, taurocholate or pancreatic ischemia followed by organ reperfusion [24-26]. Our current study confirms and extends these observations. Administration of cerulein led to the development of acute edematous pancreatitis. Pancreases were swollen, mean pancreatic weight was increased by more than $120 \%$. Microscopic examination showed interlobular and moderate or severe intralobular pancreatic edema. These alterations were accompanied by perivascular and diffuse inflammatory infiltration, and vacuolization of acinar cells. Pretreatment with ghrelin performed in rats with intact capsaicin-sensitive sensory nerves reduced the severity of cerulein-induced acute pancreatitis. It reduced pancreatic edema and other histological signs of pancreatitis. Reduction in pancreatic edema was also found as a decrease in pancreatic weight. Moreover, pretreatment with ghrelin reduced the pancreatitis-evoked increase in plasma activity of pancreatic digestive enzyme, lipase, and plasma concentration of pro-inflammatory cytokine, tumor necrosis factor- $\alpha$, whereas plasma concentration of anti-inflammatory cytokine, interleukin- 4 was enhanced. 
The increase in plasma activity of lipase is a well-known index of acute pancreatitis development and the severity of this disease with high sensitivity and specificity $[49,50]$. In our present study, induction of acute pancreatitis led to eighty-fold increase in plasma activity of lipase in comparison to the control value. Pretreatment with ghrelin decreased the pancreatitis-evoked increase in plasma activity of that pancreatic digestive enzyme. This effect seems to be a result as well as a mechanism of protective effect of ghrelin in the pancreas, which indicates that ghrelin prevents entering pancreatic enzymes to interstitial space of the pancreas and circulation. Moreover, it was found that pancreatic digestive enzymes, especially proteases induce leukocyte-endothelial adhesion leading to inflammatory infiltration and microcirculatory failure in the pancreas [51]. In acute pancreatitis, leukocytes adhere to endothelium, infiltrate pancreatic tissue and produce pro-inflammatory cytokines within this organ $[52,53]$. These data are in agreement with our present observations. In rats with intact sensory nerves, pretreatment with ghrelin reduced the cerulein-evoked increase in plasma level of lipase and this effect was associated with reduction of leukocyte infiltration of pancreatic tissue.

However, the question remains what is the mechanism by which ghrelin prevents entering of pancreatic enzymes to the circulation. In physiological condition, zymogen granules containing inactive pancreatic enzymes are secreted by exocytosis at the apical part of pancreatic acinar cells to the lumen of pancreatic acini. In the case of acute pancreatitis this process is impaired. Partly condensed vacuoles with newly synthesized digestive enzymes accumulate at the basolateral part of the acinar cell and form the large vacuoles containing digestive enzymes and lysosomal hydrolase, cathepsin D [54]. Later, mature zymogen granules and lysosomes also fuse with these large cathepsin D-containing vacuoles [55-57]. Lysosomal enzymes lead to premature intracellular activation of pancreatic enzymes and cellular organelles damage. Subsequently, these large vacuoles and individual zymogen granules fuse with the basolateral plasma membrane, discharging their content into the interstitial space and developing acute pancreatitis $[54,57,58]$. In the next step, active pancreatic digestive enzymes enter the bloodstream. These findings are in harmony with our current studies. In agreement with previous studies, we observed that administration of cerulein led to vacuolization of acinar cells. Vacuolization of acinar cells should be recognized as an index of colocalization of lysosomes and zymogens in the large vacuoles and intracellular activation of pancreatic enzymes. Our present study also showed that pretreatment with ghrelin before cerulein administration reduces vacuolization of acinar cells. This finding is an evidence that ghrelin decreases the cerulein-induced premature activation of pancreatic enzymes within acinar cells.

Our current studies also showed that administration of ghrelin reduces inflammatory leukocyte infiltration of the pancreas in cerulein-induced pancreatitis. Reduction in inflammatory infiltration decreases pancreatic damage and for this reason also reduces premature intrapancreatic activation of digestive enzymes and release of these enzymes into the circulation. Moreover, the development of acute pancreatitis is associated with generation of reactive oxygen species [59]. Excess free oxygen radicals cause oxidative damage of cellular lipids, proteins and nucleic acids. Peroxidation of cellular lipids is the first step of reactive oxygen species-mediated cellular damage. Previous studies indicated that treatment with ghrelin reduces lipid peroxidation and increases the activity of enzymes involved in deactivation of free oxygen radicals [29]. These findings show a further mechanism of action of ghrelin, which leads to a decrease in plasma level of active pancreatic enzymes.

Tumor necrosis factor- $\alpha$ (TNF- $\alpha$ ) is the best-known member of a cytokine family called the tumor necrosis factor superfamily [60]. TNF- $\alpha$ is a cell signaling cytokine involved in wide spectrum of responses to stress and injury. It is mainly produced by macrophages and other immune cells, such as monocytes, lymphocytes, natural killer cells, neutrophils and eosinophils. However, TNF- $\alpha$ can be also produced by many other cell types, including pancreatic acinar cells [61]. This cytokine exhibits host-damaging effects in different autoimmune and inflammatory diseases. TNF- $\alpha$ is an activator of immune cells and regulates the synthesis of other pro-inflammatory cytokines and leukocyte adhesion molecules. It is an endogenous pyrogen and, for this reason, it may induce fever. Moreover, this pro-inflammatory cytokine activates the cell death signaling, leading to cell apoptosis. It may induce 
cachexia and inhibit tumorigenesis, and viral replication [60,62]. Numerous studies indicate that TNF- $\alpha$ plays a pivotal role in the development of severe acute pancreatitis. Measurement of serum TNF- $\alpha$ concentration was suggested to be useful biomarker in predicting severe pancreatitis and development of multiorgan failure or septic shock [63]. However, TNF- $\alpha$ is rapidly cleared from the circulation and for this reason the potential prognostic value of its measurement is limited to the first days after the onset of the disease [62,63].

In our current study, we found that pretreatment with ghrelin in rats with intact sensory nerves reduces the pancreatitis-induced increase in plasma concentration of TNF- $\alpha$. This finding was in line with our observation that administration of ghrelin reduces pancreatic leukocyte infiltration. In addition, these findings taken together indicate that protective effect of ghrelin in cerulein-induced pancreatitis in sensory nerves-intact rats involves anti-inflammatory effect of this polypeptide.

The next interesting finding of our current study is observation that induction of acute pancreatitis by cerulein increases plasma level of interleukin-4 (IL-4) and pretreatment with ghrelin dose-dependently enhances this effect. On the other hand, ghrelin did not affect plasma level of IL-4 in rats without induction of acute pancreatitis. Previous studies showed that IL-4 exhibits anti-inflammatory effects. Hart et al. reported that IL-4 suppresses the production of pro-inflammatory interleukin-1 $\beta$ (IL-1 $\beta$ ) and TNF- $\alpha$ by monocytes stimulated with lipopolysaccharide and interferon $\gamma$, and this effect is similar to that obtained with dexamethasone [64]. Similar effects were obtained by Vannier et al. [65]. They found that IL-4 inhibits the lipopolysaccharide-induced synthesis of IL-1 $\beta$ in human peripheral blood mononuclear cells and enhanced the lipopolysaccharide-induced synthesis of anti-inflammatory IL-1 receptor antagonist. Anti-inflammatory effect of IL-4 was also found in acute pancreatitis. Protective and therapeutic effect of IL-4 in severe taurocholate-induced acute pancreatitis was reported by Zhang et al. [66]. IL-4 reduced necrosis in this model of acute pancreatitis and authors suggested that this effect was related to enhanced expression of complement regulatory proteins, CD55 and CD59. In addition, clinical studies indicate that IL-4 affects the development and course of acute pancreatitis. Acute pancreatitis, as well as endoscopic retrograde cholangiopancreatography (ERCP) increases serum level of interleukin-4. Kilciler et al. found that $24 \mathrm{~h}$ after ERCP, a level of interleukin-4 is significantly lower in patients with post-ERCP pancreatitis than in those without pancreatitis [67]. This observation suggests that the development of acute pancreatitis is the effect of imbalance between pro- and anti-inflammatory factors, while maintaining a balance between those factors prevent the development of inflammation. Too low level of anti-inflammatory IL-4 or too low increase in serum level of this cytokine in response to the presence of pro-inflammatory factors can disturb this balance and lead to the development of acute pancreatitis and/or increase in its severity. On the other hand, IL-4 was shown to stimulate the class of macrophages named alternatively activated macrophages [68]. Alternatively activated macrophages are involved in dampening inflammation and promotion of wound healing, fibrosis, and tumorigenesis. Study of Xue et al. [68] showed that mouse and human pancreatic stellate cells are source of IL-4/IL-13 and a cross talk between macrophages and pancreatic stellate cells is associated with the development and progression of chronic pancreatitis. Our present study showed that ghrelin enhances the pancreatitis-evoked increase in plasma level of IL-4. Those data could suggest that administration of ghrelin may promote the development of chronic pancreatitis. Fortunately, our present study also showed that ghrelin does not affect plasma level of interleukin- 4 in rats without induction of acute pancreatitis. For this reason, the probability that administration of ghrelin may stimulate the development of chronic pancreatitis is minimal.

Numerous clinical [69-72] and experimental [73-76] studies showed that disturbance in pancreatic microcirculation can be a primary cause of acute pancreatitis. Moreover, pancreatic microcirculation disorder and pancreatic ischemia are observed in acute pancreatitis evoked by primary non-vascular mechanism, and always these alterations increase the severity of this disease $[73,74,77]$. On the other hand, the improvement of blood flow through pancreatic vessels inhibits the development of acute pancreatitis and accelerates the recovery in this disease $[43,78,79]$. Our present study showed that after a $5-h$ administration of cerulein, pancreatic blood flow was reduced by around $40 \%$ in comparison 
to value observed in sensory nerves-intact rats without induction of acute pancreatitis. Pretreatment with ghrelin given intraperitonelly at the dose of $12.5,25 \mathrm{or} 50 \mu \mathrm{g} / \mathrm{kg}$ was without any significant effect on pancreatic blood flow in sensory nerves-intact rats without induction of acute pancreatitis, as well as in rats with induction of acute pancreatitis. We only found that pretreatment with ghrelin exhibits an insignificant tendency to improve pancreatic blood flow in sensory nerves-intact rats with acute pancreatitis. These observations are in agreement with previous studies showing lack of effect of pretreatment with ghrelin on pancreatic blood flow in cerulein- or ischemia/reperfusion-induced pancreatitis $[24,26]$. In contrast, long-term treatment with ghrelin after induction of cerulein- or ischemia/reperfusion-induced pancreatitis improved pancreatic blood flow $[27,28]$. These data taken together with our current observation suggests that influence of ghrelin on pancreatic blood flow in the course of acute pancreatitis is indirect effect likely due to improvement of pancreatic morphology. For this reason, short term observation was not able to demonstrate any effect in pancreatic circulation after a single dose of ghrelin.

We may also speculate that the lack of beneficial effects of ghrelin on pancreatic blood flow is associated with activation of coagulation in pancreatic vessels. Numerous experimental and clinical studies showed that coagulative disorders occur in acute pancreatitis [80-84]. Acute pancreatitis stimulates intravascular coagulation with formation of thrombi within blood vessels and coagulation disorders may be in the range between scattered intravascular thrombosis in pancreatic microcirculation to severe disseminated intravascular coagulation [84]. Moreover, animals and clinical studies showed that treatment with heparin or anticoagulants inhibits the development of acute pancreatitis and accelerates the recovery in this disease [85-93]. These findings indicate that disorders of coagulation play the important role in acute pancreatitis and these disorders may be responsible for the lack of significant improvement in pancreatic blood flow in animals treated with ghrelin despite improved histology of the pancreas.

The major finding of current research was to determine the role of sensory nerves in the protective effect of ghrelin in cerulein-induced pancreatitis. Ablation of sensory nerves by neurotoxic doses of capsaicin performed before induction of acute pancreatitis significantly reduced plasma concentration of anti-inflammatory IL-4 and showed a tendency to an additional increase in pancreatic weight and decrease in pancreatic blood flow. However, the last two changes were not statistically significant. Other parameters tested were not affected by ablation of sensory nerves and those observation are similar to that observed previously in cerulein-induced pancreatitis $[40,42,43]$. These data indicate that ablation of sensory nerves reduces endogenous anti-inflammatory mechanisms in the pancreas and moderately increases pancreatic damage in acute pancreatitis. On the other hand, ablation of sensory nerves totally abolished the protective effect of ghrelin in this model of acute pancreatitis. In rats with ablation of sensory nerves before induction of acute pancreatitis, pretreatment with ghrelin was without any effect on morphological signs of pancreatic damage, pancreatic weight, plasma level of pancreatic digestive enzyme, lipase or plasma concentration of TNF- $\alpha$ and IL-4. These observations indicate that sensory nerves mediate protective effect of ghrelin in the pancreas. This concept is supported by study performed by Date et al. [94]. They found the presence of ghrelin receptors in vagal afferent neurons. Vagotomy or capsaicin-induced deactivation of the gastric vagal afferent neurons eliminated ghrelin-induced food intake, growth hormone secretion, and activation of neuropeptide Y- and GH-RH-producing neurons [94].

Our current studies showed that ablation of sensory nerves by neurotoxic doses reduces pancreatic blood flow in basal condition without induction of acute pancreatitis. In rats treated with ghrelin after deactivation of sensory nerves, pancreatic blood flow was significantly reduced in comparison to a level observed in sensory nerves-intact rats without induction o acute pancreatitis and treated with saline or ghrelin. This observation brought two important pieces of information First, it indicates that, under basic conditions, sensory nerves exhibit tonic activity and participate in maintaining adequate blood flow in the pancreas. This effect seems to be related to the ability of the sensory nerves to local release of vasoactive neuromediators, mainly calcitonin gene-related peptide (CGRP) [31-33]. 
Stimulation of sensory nerves results in the release of these neuromediators, leading to vasodilatation and increase in organ blood flow [40]. Second, ablation of sensory nerves decreases plasma and tissue level of CGRP [35]. Results of this part of the study also showed that administration of ghrelin is not able to reverse the negative effect of sensory nerve ablation on pancreatic blood flow. This lack of improvement in blood flow following administration of ghrelin additionally supports the thesis about the essential role of sensory nerves in the protective action of ghrelin in the pancreas.

The last part of our present study was conducted to determine the effect of sensory nerve ablation and the administration of ghrelin, performed in rats before isolation of pancreatic acini, on acinar cell expression of mRNA for TNF- $\alpha$ and heat shock protein 70 (HSP70) and synthesis of those proteins. Exposure of isolated pancreatic acini to cerulein led to increase in cellular expression of mRNA for TNF- $\alpha$, as well as cellular synthesis of TNF- $\alpha$. In acinar cells obtained from sensory nerves-intact rats pretreated with ghrelin, expression mRNA for TNF- $\alpha$ and synthesis of this pro-inflammatory cytokine after incubation with cerulein was reduced. On the other hand, pretreatment with ghrelin was without any effect on expression of mRNA for TNF- $\alpha$ and synthesis of TNF- $\alpha$ under basic condition without the presence of cerulein. Ablation of sensory nerves, before isolation of pancreatic acini, abolished the inhibitory effect of ghrelin on the cerulein-induced expression of mRNA for TNF- $\alpha$ and synthesis of this protein.

These observations provide some important information. First, these data indicate that acinar cells may play the active role in the development of inflammation in acute pancreatitis by releasing pro-inflammatory cytokine, TNF- $\alpha$. This finding is agreement with observations of Gukovskaya et al. [95]. They found that pancreatic acinar cells produce, release, and respond to TNF- $\alpha$. In addition, this part of our study brings additional evidence that ghrelin exhibits the anti-inflammatory and protective effect in acute pancreatitis. Our present study also showed that protective effect of ghrelin on the pancreas involves the action of ghrelin on the level of pancreatic acinar cells. Moreover, these in vitro studies confirm and extend our current observations obtained in the first part of our research in animal model of acute pancreatitis that the protective effect of ghrelin in acute pancreatitis is mediated by capsaicin-sensitive sensory nerves.

The next interesting discovery of our current study is the observations on the effect of ghrelin on expression and production of HSP70 in isolated pancreatic acini. HSPs are highly conserved cytoprotective proteins. Their synthesis can be induced by various stressors such as hyper- and hypothermia, toxins, heavy metals, and free radicals [96]. HSPs play a role of molecular chaperons in folding newly synthesized cell proteins and assisting in the refolding of damaged proteins. HSP70 is located in all cellular compartments, including the endoplasmic reticulum, mitochondria, cytosol and nucleus [97]. Previous studies performed on the animals demonstrated that both, thermal and non-thermal stresses inhibit the development of cerulein-induced pancreatitis and prevent premature trypsinogen activation in pancreatic tissue and this effect was shown to be mediated by HSP70 [98]. HSPs are also involved in thermal-induced protection against arginine- and taurocholate-induced acute pancreatitis $[99,100]$. Protective effect of ischemic preconditioning in the pancreas is associated with increase in synthesis of HSP70 [101]. The protective mechanisms of HSPs in the pancreas include stabilization and refolding of damaged proteins, resistance of cells to apoptosis or necrosis, decrease in the level of pro-inflammatory cytokines, antioxidant effects and inhibition of zymogen activation within pancreatic acinar cells $[96,98,102]$. Our present observation that incubation of isolated pancreatic acini with cerulein induces production of HSP70 in acinar cells is in harmony with previous studies showing the increase in HSP70 at the mRNA and protein level in the pancreas in cerulein-induced acute pancreatitis $[103,104]$. The major finding of this part of our present research is observation that administration of ghrelin stimulates the expression of mRNA for HSP70 and production of HSP70 in pancreatic acini isolated from rats with intact sensory nerves. This effect was found in acini incubated in a cerulein-depleted medium. Moreover, the administration of ghrelin augmented the stimulatory effect of cerulein on HSP expression and production. In contrast, ghrelin failed to induce expression and production of HSP70 in pancreatic acini obtained from rats with ablated capsaicin-sensitive 
sensory nerves. These findings are the next evidence that the maintenance of sensory nerves integrity is necessary for protective effect of ghrelin in the pancreas.

\section{Material and Methods}

The research was conducted in accordance with the protocols approved by the Jagiellonian University Ethical Committee for Research and Animal Ethics. Experiments were carried out in two series: in vivo and in vitro studies.

\subsection{In Vivo Studies}

\subsubsection{Animals and Treatment}

In vivo studies were performed on male Wistar rats weighing 170-200 g. Rats were housed in cages in standard conditions at room temperature with a normal circadian rhythm; 12-h day/night cycle. During a one-week period of acclimation to a new environment, food (commercial pellet chow) and water were available ad libitum.

All experimental procedures performed in this study were approved by the Jagiellonian University Ethical Committee on Animals Experimentation (Permit No ZI/UJ/118/2001 released on July 20, 2001). Animals were deprived of food with free access to water $24 \mathrm{~h}$ prior to the start of experiment.

Rats participating in in vivo studies were randomly divided into 11 experimental groups (each containing 10-15 animals) as follows:

(1) Control group: sensory nerves-intact rats treated with saline given as a single intaperitoneal (i.p.) injection followed by subcutaneous (s.c.) infusion for $5 \mathrm{~h}$;

(2) Sensory nerves-intact rats treated with ghrelin given at a dose of $12.5 \mu \mathrm{g} / \mathrm{kg}$ as single i.p. injection followed by s.c. infusion of saline for $5 \mathrm{~h}$;

(3) Sensory nerves-intact rats treated with ghrelin given at a dose of $25 \mu \mathrm{g} / \mathrm{kg}$ as single i.p. injection followed by s.c. infusion of saline for $5 \mathrm{~h}$;

(4) Sensory nerves-intact rats treated with ghrelin given at a dose of $50 \mu \mathrm{g} / \mathrm{kg}$ as single i.p. injection followed by s.c. infusion of saline for $5 \mathrm{~h}$;

(5) Sensory nerves-intact rats treated with saline given as single i.p. injection followed by induction of acute pancreatitis (AP) by s.c. infusion of cerulein for $5 \mathrm{~h}$;

(6) Sensory nerves-intact rats treated with ghrelin given at a dose of $12.5 \mu \mathrm{g} / \mathrm{kg}$ as single i.p. injection followed by induction of AP by s.c. infusion of cerulein for $5 \mathrm{~h}$;

(7) Sensory nerves-intact rats treated with ghrelin given at a dose of $25 \mu \mathrm{g} / \mathrm{kg}$ as single i.p. injection followed by induction of AP by s.c. infusion of cerulein for $5 \mathrm{~h}$;

(8) Sensory nerves-intact rats treated with ghrelin given at a dose of $50 \mu \mathrm{g} / \mathrm{kg}$ as single i.p. injection followed by induction of AP by s.c. infusion of cerulein for $5 \mathrm{~h}$;

(9) Rats with capsaicin deactivation of sensory nerves (CDSN) treated with saline given as single i.p. injection followed by induction of AP by s.c. infusion of cerulein for $5 \mathrm{~h}$;

(10) Rats with CDSN treated with ghrelin given at a dose of $50 \mu \mathrm{g} / \mathrm{kg}$ as single i.p. injection followed by induction of AP by s.c. infusion of cerulein for $5 \mathrm{~h}$; and

(11) Rats with CDSN treated with ghrelin given at a dose of $50 \mu \mathrm{g} / \mathrm{kg}$ as single i.p. injection followed by s.c. infusion of saline for $5 \mathrm{~h}$.

Acute pancreatitis (AP) was induced by s.c. infusion of cerulein (Takus, Pharmacia, GmbH, Erlangen, Germany) at a dose of $5 \mu \mathrm{g} / \mathrm{kg} / \mathrm{h}$ for $5 \mathrm{~h}$. Cerulein was diluted in saline and infused at a rate of $1 \mathrm{~mL} / \mathrm{h}$. Control groups received s.c. infusion of saline for $5 \mathrm{~h}(1 \mathrm{~mL} / \mathrm{h})$ as described previously [105]. Thirty minutes before the start of cerulein or saline infusion, rats were treated with tramadol (Poltram, Polpharma, Starogard Gdański, Poland) given intramuscularly at a dose of $1 \mathrm{mg} / \mathrm{kg}$ to minimize pain and distress. During s.c. infusion of cerulein or saline, conscious rats were placed in individual Bollman cages. All experiments were carried out in the morning. 
Capsaicin deactivation of sensory nerves (CDSN) was performed by neurotoxic doses of capsaicin (Fluka, Buchs, Switzerland) given s.c. during 3 days at a total dose of $100.0 \mathrm{mg} / \mathrm{kg}, 7$ days prior to induction of acute pancreatitis or infusion of saline [106].

Ghrelin (Bachem AG, Budendorf, Switzerland) dissolved in $0.5 \mathrm{~mL}$ of $0.9 \% \mathrm{NaCl}$, was given i.p. to rats with intact sensory nerves or rats with CDSN, $30 \mathrm{~min}$ before the infusion of $0.9 \% \mathrm{NaCl}$ (control group) or cerulein (AP). Rats with intact sensory nerves were treated with ghrelin given at a dose of 12.5, 25 or $50 \mu \mathrm{g} / \mathrm{kg}$. Rats with CDSN were treated with ghrelin given at one dose of $50 \mu \mathrm{g} / \mathrm{kg}$, because this dose exhibited the greatest protective effect on the pancreas in rats with intact sensory nerves.

\subsubsection{Determination of Pancreatic Blood Flow}

Following 5-h infusion of saline or cerulein, the rats were anesthetized with pentobarbital (30 mg/kg i.p., Vetbutal, Biowet, Puławy, Poland) and then the abdominal cavity was opened. Pancreatic blood flow was measured by a laser Doppler flowmeter using a Laserflo, model BPM 403 A (Blood Perfusion Monitor, Vasdamedics Inc., St. Paul, MN, USA) as previously described [107]. Blood flow was measured in five different pancreatic regions in each rat and expressed as the percent change of the control value.

\subsubsection{Biochemical Parameters}

Immediately after the measurement of pancreatic blood flow, blood samples were taken from the inferior vena cava for plasma measurement of lipase, tumor necrosis factor- $\alpha$ (TNF- $\alpha$ ) and interleukin-4 (IL-4).

Lipase activity was determined using LIPA DT Slides (Vitros DT Chemistry System, Johnson \& Johnson Clinical Diagnostic, Inc., Rochester, NY, USA). The reading was made using the Kodak Ectachem DT II System analyzer (Eastman Kodak Company, Rochester, NY, USA) [108].

TNF- $\alpha$ and IL- 4 concentrations were determined by immunoenzymatic assay (ELISA) using rat diagnostic tests (Biosource International, Camarillo, CA, USA) [107].

\subsubsection{Pancreatic Weight and Histological Examination}

The pancreas was carefully isolated from the abdominal cavity of each animal, purified from adipose tissue, rinsed in $0.9 \% \mathrm{NaCl}$, filtered and weighed.

Histological studies were carried out on pancreatic samples fixed in $10 \%$ formalin and stained with hematoxylin and eosin (H\&E). Specimens were examined by a professional pathologist. Histological grading of pancreatic edema, leukocyte inflammatory infiltration, vacuolization of acinar cells was made using a scale ranging from 0 to 3 as described previously in detail [108,109]:

1. pancreatic edema (0-no edema, 1-interlobar edema, 2-interlobar and moderate intralobular edema, 3-severe interlobula and intralobular edema);

2. leukocyte inflammatory infiltration (0-Absent, 1 -scarce perivascular infiltration, 2-moderate perivascular and scarce diffuse infiltration, 3-abundant diffuse infiltration);

3. vacuolozation of acinar cells ( 0 -absent, 1 -involving less than $25 \%$ of acinar cells, 2 -involving from 25 to $50 \%$ acinar cells, 3 -involving more than $50 \%$ of acinar cells);

4. necrosis of acinar cells ( 0 -absent, 1 -involving less than $15 \%$ of acinar cells, 2 -involving from 15 to $35 \%$ acinar cells, 3 -involving more than $35 \%$ of acinar cells); and

5. hemorrhage (0-absent, 1 from 1 to 2 foci per slide, 2 -from 3 to 5 foci per slide, 3 -more than 5 foci per slide).

The results of histological examination were shown as predominant histological grading (mode) of pancreatic edema, inflammatory infiltration and vacuolization of acinar cells in each experimental group (Table 1). Moreover, we showed the representative morphological features of the pancreas in main experimental groups in Figure 2 and the total histological score of pancreatic damage calculated 
as the sum of degrees of pancreatic edema, inflammatory infiltration and vacuolization of acinar cells as described previously [110].

\subsection{In Vitro Studies}

Isolated acinar cells were obtained from rats with intact sensory nerves or rats with CDSN. Rats were treated with ghrelin given i.p. at single dose of $50 \mu \mathrm{g} / \mathrm{kg}$ or with saline and $48 \mathrm{~h}$ later as described previously [111], animals were again anesthetized with pentobarbital. The abdominal cavity was opened and the pancreas was carefully dissected out from its attachment to the stomach, duodenum and spleen. Pancreatic acinar cells were isolated by collagenase digestion as described previously [112,113] and incubated in cerulein-free or cerulein containing solution. Previous studies showed that cerulein given at a concentration of $10^{-8} \mathrm{M}$ and 5-h incubation were most effective in stimulating exocrine secretion and gene expression in pancreatic acinar cells [114,115], thus these concentration of cerulein and time of incubation were selected for our current in vitro studies. Studies in each experimental group were repeated at least six times.

During the in vitro studies, we used following experimental groups:

(1) acinar cells obtained from control sensory nerves-intact rats treated i.p. with saline; after isolation, acinar cells incubated in cerulein-free solution;

(2) acinar cells obtained from sensory nerves-intact rats treated i.p. with ghrelin at a dose of $50 \mu \mathrm{g} / \mathrm{kg}$; after isolation, acinar cells incubated in cerulein-free solution;

(3) acinar cells obtained from sensory nerves-intact rats treated i.p. with saline; after isolation, acinar cells incubated in solution containing cerulein at a concentration of $10^{-8} \mathrm{M}$;

(4) acinar cells obtained from sensory nerves-intact rats treated i.p. with ghrelin at a dose of $50 \mu \mathrm{g} / \mathrm{kg}$; after isolation, acinar cells incubated in solution containing cerulein at a concentration of $10^{-8} \mathrm{M}$;

(5) acinar cells obtained from rats with CDSN treated i.p. with saline; after isolation, acinar cells incubated in solution containing cerulein at a concentration of $10^{-8} \mathrm{M}$;

(6) acinar cells obtained from rats with CDSN treated i.p. with ghrelin at a dose of $50 \mu \mathrm{g} / \mathrm{kg}$; after isolation, acinar cells incubated in solution containing cerulein at a concentration of $10^{-8} \mathrm{M}$; and

(7) acinar cells obtained from rats with CDSN treated i.p. with ghrelin at a dose of $50 \mu \mathrm{g} / \mathrm{kg}$; after isolation, acinar cells incubated in cerulein-free solution.

4.2.1. Determination of TNF- $\alpha$ and Heat Shock Protein 70 (HSP70) Gene Expression by Reverse Transcription-Polymerase Chain Reaction (RT-PCR)

The isolation of total cellular RNA was performed employing TRIzol Reagent (Gibco-BRL, Life Technologies, Gaithersburg, MD, USA) in accordance with the manufacturer's protocol [116]. Precipitated in the final step of isolation, RNA was resuspended in RNase-free water. Final concentration of the RNA isolates was estimated by the measurement of absorbance at $260 \mathrm{~nm}$ wavelength. To establish the purity of the isolates calculation of A260/A280 ratio was done. The integrity of RNA isolates was confirmed by electrophoresis in formaldehyde denaturizing conditions.

cDNA synthesis was performed employing the Reverse Transcription System (Promega Corp., Madison, WI, USA) using $1 \mu \mathrm{g}$ of RNA according to the manufacturers protocol. Two of the cDNAs were used for polymerase chain reaction. Promega PCR reagents were used in all PCR reactions. Specific primers were synthesized by Sigma-Genosys (Pampisford, UK). Semi-quantitative analysis of the abundance of cDNA product for each sample was performed using Foto/Analyst Fotodyne System (Fotodyne Inc., Hartland, WI, USA) on ethidium bromide stained 2\% agarose gel. O'Gene Ruler $50 \mathrm{bp}$ DNA Ladder (Fermentas GmbH, St. Leon-Rot, Germany) was used to confirm the predicted location of the PCR products. Results of the semi-quantitative analysis were expressed as a ratio using $\beta$-actin 
gene product as a reference for each sample. PCR negative and positive reaction controls were added in all experiments to confirm specificity of reaction.

The gene, primer sequences, product length, characteristic annealing temperatures and references are summarized in Table 2.

Table 2. Gene, primers' sequences, product length, annealing temperatures, references.

\begin{tabular}{|c|c|c|c|c|}
\hline Gene & Sequence $5^{\prime} \rightarrow 3^{\prime}$ & Product (bp) & $\begin{array}{c}\text { Annealing } \\
\text { Temperature }\left({ }^{\circ} \mathrm{C}\right)\end{array}$ & Reference \\
\hline$\beta$-actin & $\begin{array}{l}\text { Sense: TTG TAA CCA ACT GGG ACG ATA TGG } \\
\text { Antisense: GAT CTT GAT CTT CAT GGT GCT AGG }\end{array}$ & 764 & 60 & [117] \\
\hline$T N F-\alpha$ & $\begin{array}{l}\text { Sense: TAC TGA ACT TCG GGG TGA TTG GTC C } \\
\text { Antisense: CAG CCT TGT CCC TTG AAG AGA ACC }\end{array}$ & 295 & 60 & [118] \\
\hline HSP70 & $\begin{array}{c}\text { Sense: GTG AAG ATC TGC GTC TGC TTG } \\
\text { Antisense: TTT GAC AAC AGG CTG GTG AAC C }\end{array}$ & 590 & 60 & [104] \\
\hline
\end{tabular}

\subsubsection{Determination of TNF- $\alpha$ and HSP70 Protein Synthesis by Immunoblotting}

The whole cell protein extracts from rat pancreatic acinar cells were prepared as described previously [119]. Samples containing 5-10 $\mu \mathrm{g}$ of proteins were separated under denaturing condition in $12 \%$ polyacrylamide gel. Following separation samples were transferred onto the PVDF membrane (BioRad, Hecules, CA, USA) and membranes were blocked for $2 \mathrm{~h}$ at room temperature in blocking buffer (5\% non-fat dried milk in PBS). Membranes containing immobilized protein samples were exposed to the primary antibody diluted 1:1000 for $1 \mathrm{~h}$ at room temperature on the agitating platform. After antibody probing membranes were washed three times for $10 \mathrm{~min}$ in TBST buffer (0.1 M Tris $\mathrm{pH}$ 8.0; $1.5 \mathrm{M} \mathrm{NaCl} ; 0.5 \%$ TritonX-100). Suitable secondary antibody in the dilution 1:5000 in blocking buffer was applied for $1 \mathrm{~h}$ at room temperature. Following the secondary antibodies probing, washing procedure was performed as described above. Each blot was stripped and probed with GAPDH antibody to confirm equal protein loading. Proteins complexed with antibodies were detected using Super Signal West Pico Chemiluminescent Substrate Thermo Fisher Scientific (Waltham, MA, USA) according to the manufactures protocol. All presented results were obtained in six consecutive experiments.

All primary antibodies: mouse monoclonal IgG1 anti GAPDH (A-3); goat polyclonal IgG anti TNF- $\alpha$ (R-19); mouse monoclonal IgG1 anti HSP70 (3A3) as well as secondary goat anti-mouse IgG1-HRP conjugated and rabbit anti-goat IgG-HRP conjugated were purchased from Santa Cruz Biotechnology (Santa Cruz, CA, USA).

\subsection{Statistical Analysis}

Results are expressed as means \pm SEM. A statistical analysis was done by one-way analysis of variance (ANOVA), followed by Tukey's multiple comparison test. A statistical analysis was conducted using the statistical package GraphPad Prism (GraphPad Software, San Diego, CA, USA). Differences with $p<0.05$ were considered significant.

\section{Conclusions}

Our present study has demonstrated that ghrelin exhibits the protective effect in cerulein-induced acute pancreatitis on the organ and pancreatic acinar cell level. The maintenance of sensory nerve integrity is necessary for this effect.

Acknowledgments: This study was supported by a grant from the Polish Committee of Scientific Research (Grant No. 2 P05B 011 26). Costs of publication were paid by the Leading National Research Center in Kraków (KNOW).

Author Contributions: Joanna Bonior created the concept and the whole research project. She was also in charge of data collection and preparing the manuscript, tables and figures. Piotr Ceranowicz, Ryszard Gajdosz, 
Beata Kuśnierz-Cabala, Piotr Pierzchalski, Zygmunt Warzecha, Artur Dembiński, Michał Pędziwiatr, Michalina Kot, Anna Leja-Szpak, Katarzyna Nawrot-Porabka, Paweł Link-Lenczowski, Rafał Olszanecki, Krzysztof Bartuś, Rafał Trabka and Jolanta Jaworek contributed to the concept of this study, especially in the field of medical utilizations and statistics. Piotr Pierzchalski and Piotr Ceranowicz helped Joanna Bonior in data collection and laboratory work. Joanna Bonior and Krzysztof Bartuś did the statistical work. Zygmunt Warzecha and Piotr Ceranowicz observed and created the idea of this study, helping Joanna Bonior in manuscript preparation and the final critical review. Joanna Bonior and Piotr Ceranowicz take responsibility for the integrity of the data and accuracy of the data analysis. All authors reviewed the manuscript.

Conflicts of Interest: The authors declare no conflict of interest.

\section{References}

1. Kojima, M.; Hosoda, H.; Date, Y.; Nakazato, M.; Matsuo, H.; Kangawa, K. Ghrelin is a growth-hormone releasing acylated peptide from stomach. Nature 1999, 402, 656-660. [CrossRef] [PubMed]

2. Ariyasu, H.; Takaya, K.; Tagami, T.; Ogawa, Y.; Hosoda, K.; Akamizu, T.; Suda, M.; Koh, T.; Natsui, K.; Toyooka, S.; et al. Stomach is a major source of circulating ghrelin, and feeding state determines plasma ghrelin-like immunoreactivity levels in humans. J. Clin. Endocrinol. Metab. 2001, 86, 4753-4758. [CrossRef] [PubMed]

3. Ceranowicz, P.; Warzecha, Z.; Dembinski, A. Peptidyl hormones of endocrine cells origin in the gut-their discovery and physiological relevance. J. Physiol. Pharmacol. 2015, 66, 11-27. [PubMed]

4. Davenport, A.P.; Bonner, T.I.; Foord, S.M.; Harmar, A.J.; Neubig, R.R.; Pin, J.P.; Spedding, M.; Kojima, M.; Kangawa, K. International Union of Pharmacology. LVI. Ghrelin receptor nomenclature, distribution, and function. Pharmacol. Rev. 2005, 57, 541-546. [CrossRef] [PubMed]

5. Tannenbaum, G.S.; Lapointe, M.; Beaudet, A.; Howard, A.D. Expression of growth hormone secretagogue-receptors by growth hormone-releasing hormone neurons in the mediobasal hypothalamus. Endocrinology 1998, 139, 4420-4423. [CrossRef] [PubMed]

6. Tschöp, M.; Flora, D.B.; Mayer, J.P.; Heiman, M.L. Hypophysectomy prevents ghrelin-induced adiposity and increases gastric ghrelin secretion in rats. Obes. Res. 2002, 10, 991-999. [CrossRef] [PubMed]

7. Bagnasco, M.; Tulipano, G.; Melis, M.R.; Argiolas, A.; Cocchi, D.; Muller, E.E. Endogenous ghrelin is an orexigenic peptide acting in the arcuate nucleus in response to fasting. Regul. Pept. 2003, 111, 161-167. [CrossRef]

8. Yokote, R.; Sato, M.; Matsubara, S.; Ohye, H.; Niimi, M.; Murao, K.; Takahara, J. Molecular cloning and gene expression of growth hormone-releasing peptide receptor in rat tissues. Peptides 1998, 19, 15-20. [CrossRef]

9. Gnanapavan, S.; Kola, B.; Bustin, S.A.; Morris, D.G.; McGee, P.; Fairclough, P.; Bhattacharya, S.; Carpenter, R.; Grossman, A.B.; Korbonits, M. The tissue distribution of the mRNA of ghrelin and subtypes of its receptor, GHS-R, in humans. J. Clin. Endocrinol. Metab. 2002, 87, 2988-2991. [CrossRef] [PubMed]

10. Dixit, V.D.; Schaffer, E.M.; Pyle, R.S.; Collins, G.D.; Sakthivel, S.K.; Palaniappan, R.; Lillard, J.W., Jr.; Taub, D.D. Ghrelin inhibits leptin- and activation-induced proinflammatory cytokine expression by human monocytes and T cells. J. Clin. Investig. 2004, 114, 57-66. [CrossRef] [PubMed]

11. Sibilia, V.; Rindi, G.; Pagani, F.; Rapetti, D.; Locatelli, V.; Torsello, A.; Campanini, N.; Deghenghi, R.; Netti, C. Ghrelin protects against ethanol-induced gastric ulcers in rats: Studies on the mechanisms of action. Endocrinology 2003, 144, 353-359. [CrossRef] [PubMed]

12. Brzozowski, T.; Konturek, P.C.; Konturek, S.J.; Kwiecień, S.; Drozdowicz, D.; Bielanski, W.; Pajdo, R.; Ptak, A.; Nikiforuk, A.; Pawlik, W.W.; et al. Exogenous and endogenous ghrelin in gastroprotection against stress-induced gastric damage. Regul. Pept. 2004, 120, 39-51. [CrossRef] [PubMed]

13. Işeri, S.O.; Sener, G.; Yüksel, M.; Contuk, G.; Cetinel, S.; Gedik, N.; Yegen, B.C. Ghrelin against alendronate-induced gastric damage in rats. J. Endocrinol. 2005, 187, 399-406. [CrossRef] [PubMed]

14. Warzecha, Z.; Kownacki, P.; Ceranowicz, P.; Dembiński, M.; Cieszkowski, J.; Dembiński, A. Ghrelin accelerates the healing of oral ulcers in non-sialoadenectomized and sialoadenectomized rats. J. Physiol. Pharmacol. 2013, 64, 657-668. [PubMed]

15. Ceranowicz, P.; Warzecha, Z.; Dembinski, A.; Sendur, R.; Cieszkowski, J.; Ceranowicz, D.; Pawlik, W.W.; Kuwahara, A.; Kato, I.; Konturek, P.C. Treatment with ghrelin accelerates the healing of acetic acid-induced gastric and duodenal ulcers in rats. J. Physiol. Pharmacol. 2009, 60, 87-98. [PubMed] 
16. Warzecha, Z.; Ceranowicz, P.; Dembinski, M.; Cieszkowski, J.; Ginter, G.; Ptak-Belowska, A.; Dembinski, A. Involvement of cyclooxygenase- 1 and cyclooxygenase- 2 activity in the therapeutic effect of ghrelin in the course of ethanol-induced gastric ulcers in rats. J. Physiol. Pharmacol. 2014, 65, 95-106. [PubMed]

17. Warzecha, Z.; Ceranowicz, D.; Dembiński, A.; Ceranowicz, P.; Cieszkowski, J.; Kuwahara, A.; Kato, I.; Dembiński, M.; Konturek, P.C. Ghrelin accelerates the healing of cysteamine-induced duodenal ulcers in rats. Med. Sci. Monit. 2012, 18, BR181-BR187. [CrossRef] [PubMed]

18. Konturek, P.C.; Brzozowski, T.; Engel, M.; Burnat, G.; Gaca, P.; Kwiecien, S.; Pajdo, R.; Konturek, S.J. Ghrelin ameliorates colonic inflammation. Role of nitric oxide and sensory nerves. J. Physiol. Pharmacol. 2009, 60, 41-47. [PubMed]

19. Gonzalez-Rey, E.; Chorny, A.; Delgado, M. Therapeutic action of ghrelin in a mouse model of colitis. Gastroenterology 2006, 130, 1707-1720. [CrossRef] [PubMed]

20. Pamukcu, O.; Kumral, Z.N.; Ercan, F.; Yegen, B.C.; Ertem, D. Anti-inflammatory effect of obestatin and ghrelin in dextran sulfate sodium-induced colitis in rats. J. Pediatr. Gastroenterol. Nutr. 2013, 57, 211-218. [CrossRef] [PubMed]

21. Matuszyk, A.; Ceranowicz, D.; Warzecha, Z.; Ceranowicz, P.; Fyderek, K.; Gałązka, K.; Cieszkowski, J.; Bonior, J.; Jaworek, J.; Pihut, M.; et al. The influence of ghrelin on the development of dextran sodium sulfate-induced colitis in rats. BioMed Res. Int. 2015, 2015, 718314. [CrossRef] [PubMed]

22. Maduzia, D.; Matuszyk, A.; Ceranowicz, D.; Warzecha, Z.; Ceranowicz, P.; Fyderek, K.; Galazka, K.; Dembinski, A. The influence of pretreatment with ghrelin on the development of acetic-acid-induced colitis in rats. J. Physiol. Pharmacol. 2015, 66, 875-885. [PubMed]

23. Matuszyk, A.; Ceranowicz, P.; Warzecha, Z.; Cieszkowski, J.; Ceranowicz, D.; Gałązka, K.; Bonior, J.; Jaworek, J.; Bartuś, K.; Gil, K.; et al. Exogenous ghrelin accelerates the healing of acetic acid-induced colitis in rats. Int. J. Mol. Sci. 2016, 17, E1455. [CrossRef] [PubMed]

24. Dembinski, A.; Warzecha, Z.; Ceranowicz, P.; Tomaszewska, R.; Stachura, J.; Konturek, S.J.; Konturek, P.C. Ghrelin attenuates the development of acute pancreatitis in rats. J. Physiol. Pharmacol. 2003, 54, 561-573. [PubMed]

25. Zhou, X.; Xue, C. Ghrelin inhibits the development of acute pancreatitis and nuclear factor $\mathrm{\kappa B}$ activation in pancreas and liver. Pancreas 2009, 38, 752-757. [CrossRef] [PubMed]

26. Dembiński, A.; Warzecha, Z.; Ceranowicz, P.; Cieszkowski, J.; Pawlik, W.W.; Tomaszewska, R.; Kuśnierz-Cabala, B.; Naskalski, J.W.; Kuwahara, A.; Kato, I. Role of growth hormone and insulin-like growth factor-1 in the protective effect of ghrelin in ischemia/reperfusion-induced acute pancreatitis. Growth Horm. IGF Res. 2006, 16, 348-356. [CrossRef] [PubMed]

27. Warzecha, Z.; Ceranowicz, P.; Dembinski, A.; Cieszkowski, J.; Kusnierz-Cabala, B.; Tomaszewska, R.; Kuwahara, A.; Kato, I. Therapeutic effect of ghrelin in the course of cerulein-induced acute pancreatitis in rats. J. Physiol. Pharmacol. 2010, 61, 419-427. [PubMed]

28. Ceranowicz, D.; Warzecha, Z.; Dembinski, A.; Ceranowicz, P.; Cieszkowski, J.; Kusnierz-Cabala, B.; Tomaszewska, R.; Kuwahara, A.; Kato, I. Role of hormonal axis, growth hormone-IGF-1, in the therapeutic effect of ghrelin in the course of cerulein-induced acute pancreatitis. J. Physiol. Pharmacol. 2010, 61, 599-606. [PubMed]

29. Bukowczan, J.; Warzecha, Z.; Ceranowicz, P.; Kuśnierz-Cabala, B.; Tomaszewska, R.; Dembiński, A. Therapeutic effect of ghrelin in the course of ischemia/reperfusion-induced acute pancreatitis. Curr. Pharm. Des. 2015, 21, 2284-2290. [CrossRef] [PubMed]

30. Zhou, X.; Xue, C. Ghrelin attenuates acute pancreatitis-induced lung injury and inhibits substance $\mathrm{P}$ expression. Am. J. Med. Sci. 2010, 339, 49-54. [CrossRef] [PubMed]

31. Holzer, P. Capsaicin: Cellular targets, mechanisms of action, and selectivity for thin sensory neurons. Pharmacol. Rev. 1991, 43, 143-201. [PubMed]

32. Szolcsányi, J. Forty years in capsaicin research for sensory pharmacology and physiology. Neuropeptides 2004, 38, 377-384. [CrossRef] [PubMed]

33. Caterina, M.J.; Schumacher, M.A.; Tominaga, M.; Rosen, T.A.; Levine, J.D.; Julius, D. The capsaicin receptor: A heat-activated ion channel in the pain pathway. Nature 1997, 389, 816-824. [PubMed]

34. Hayes, P.; Meadows, H.J.; Gunthorpe, M.J.; Harries, M.H.; Duckworth, D.M.; Cairns, W.; Harrison, D.C.; Clarke, C.E.; Ellington, K.; Prinjha, R.K.; et al. Cloning and functional expression of a human orthologue of rat vanilloid receptor-1. Pain 2000, 88, 205-215. [CrossRef] 
35. Wimalawansa, S.J. The effects of neonatal capsaicin on plasma levels and tissue contents of CGRP. Peptides 1993, 14, 247-252. [CrossRef]

36. Clementi, G.; Amico-Roxas, M.; Caruso, A.; Cutuli, V.M.; Maugeri, S.; Prato, A. Protective effects of calcitonin gene-related peptide in different experimental models of gastric ulcers. Eur J. Pharmacol. 1993, 238, 101-104. [CrossRef]

37. Holzer, P.; Lippe, I.T. Stimulation of afferent nerve endings by intragastric capsaicin protects against ethanol-induced damage of gastric mucosa. Neuroscience 1988, 27, 981-987. [CrossRef]

38. Brzozowski, T.; Konturek, S.J.; Pytko-Polończyk, J.; Warzecha, Z. Gastric adaptation to stress: Role of sensory nerves, salivary glands and adrenal glands. Scand. J. Gastroenterol. 1995, 30, 6-16. [CrossRef] [PubMed]

39. Takeuchi, K.; Ohuchi, T.; Okabe, S. Capsaicin-sensitive sensory neurons in healing gastric lesions induced by $\mathrm{HCl}$ in rats. Dig. Dis. Sci. 1994, 39, 2543-2546. [CrossRef] [PubMed]

40. Dembinski, A.; Warzecha, Z.; Konturek, P.J.; Ceranowicz, P.; Konturek, S.J. Influence of capsaicin-sensitive afferent neurons and nitric oxide (NO) on cerulein-induced pancreatitis in rats. Int. J. Pancreatol. 1996, 19, 179-189. [PubMed]

41. Dembiński, A.; Warzecha, Z.; Ceranowicz, P.; Jaworek, J.; Sendur, R.; Knafel, A.; Dembiński, M.; Bilski, J.; Pawlik, W.W.; Tomaszewska, R.; et al. Stimulation of sensory nerves and CGRP attenuate pancreatic damage in ischemia/reperfusion induced pancreatitis. Med. Sci. Monit. 2003, 9, BR418-BR425. [PubMed]

42. Warzecha, Z.; Dembiński, A.; Jaworek, J.; Ceranowicz, P.; Szlachcic, A.; Walocha, J.; Konturek, S.J. Role of sensory nerves in pancreatic secretion and caerulein-induced pancreatitis. J. Physiol. Pharmacol. 1997, 48, 43-58. [PubMed]

43. Warzecha, Z.; Dembiński, A.; Ceranowicz, P.; Konturek, P.C.; Stachura, J.; Konturek, S.J.; Niemiec, J. Protective effect of calcitonin gene-related peptide against caerulein-induced pancreatitis in rats. J. Physiol. Pharmacol. 1997, 48, 775-787. [PubMed]

44. Warzecha, Z.; Dembiński, A.; Ceranowicz, P.; Konturek, P.C.; Stachura, J.; Tomaszewska, R.; Konturek, S.J. Calcitonin gene-related peptide can attenuate or augment pancreatic damage in caerulein-induced pancreatitis in rats. J. Physiol. Pharmacol. 1999, 50, 49-62. [PubMed]

45. Warzecha, Z.; Dembiński, A.; Ceranowicz, P.; Konturek, P.C.; Niemiec, J.; Stachura, J.; Tomaszewska, R.; Konturek, S.J. The influence of sensory nerves and CGRP on the pancreatic regeneration after repeated episodes of acute pancreatitis in rats. J. Physiol. Pharmacol. 2000, 51, 449-461. [PubMed]

46. Grady, E.F.; Yoshimi, S.K.; Maa, J.; Valeroso, D.; Vartanian, R.K.; Rahim, S.; Kim, E.H.; Gerard, C.; Gerard, N.; Bunnett, N.W.; et al. Substance P mediates inflammatory oedema in acute pancreatitis via activation of the neurokinin-1 receptor in rats and mice. Br. J. Pharmacol. 2000, 130, 505-512. [CrossRef] [PubMed]

47. Hegde, A.; Bhatia, M. Neurogenic inflammation in acute pancreatitis. JOP 2005, 6, 417-421. [PubMed]

48. Li, Q.; Peng, J. Sensory nerves and pancreatitis. Gland Surg. 2014, 3, 284-292. [CrossRef] [PubMed]

49. Dervenis, C.; Johnson, C.D.; Bassi, C.; Bradley, E.; Imrie, C.W.; McMahon, M.J.; Modlin, I. Diagnosis, objective assessment of severity, and management of acute pancreatitis. Santorini consensus conference. Int. J. Pancreatol. 1999, 25, 195-210. [PubMed]

50. Fabre, A.; Boulogne, O.; Gaudart, J.; Mas, E.; Olives, J.P.; Sarles, J. Evaluation of serum lipase as predictor of severity of acute pancreatitis in children. J. Pediatr. Gastroenterol. Nutr. 2014, 58, e41-e42. [CrossRef] [PubMed]

51. Keck, T.; Friebe, V.; Warshaw, A.L.; Antoniu, B.A.; Waneck, G.; Benz, S.; Hopt, U.T.; Fernández-del-Castillo, C. Pancreatic proteases in serum induce leukocyte-endothelial adhesion and pancreatic microcirculatory failure. Pancreatology 2005, 5, 241-250. [CrossRef] [PubMed]

52. Fink, G.W.; Norman, J.G. Intrapancreatic interleukin-1 $\beta$ gene expression by specific leukocyte populations during acute pancreatitis. J. Surg. Res. 1996, 63, 369-373. [CrossRef] [PubMed]

53. Kingsnorth, A. Role of cytokines and their inhibitors in acute pancreatitis. Gut 1997, 40, 1-4. [CrossRef] [PubMed]

54. Adler, G.; Rohr, G.; Kern, H.F. Alteration of membrane fusion as a cause of acute pancreatitis in the rat. Dig. Dis. Sci. 1982, 27, 993-1002. [CrossRef] [PubMed]

55. Adler, G.; Hahn, C.; Kern, H.F.; Rao, K.N. Cerulein-induced pancreatitis in rats: Increased lysosomal enzyme activity and autophagocytosis. Digestion 1985, 32, 10-18. [CrossRef] [PubMed]

56. Saluja, A.; Hashimoto, S.; Saluja, M.; Powers, R.E.; Meldolesi, J.; Steer, M.L. Subcellular redistribution of lysosomal enzymes during caerulein-induced pancreatitis. Am. J. Physiol. 1987, 253, G508-G516. [PubMed] 
57. Saito, I.; Hashimoto, S.; Saluja, A.; Steer, M.L.; Meldolesi, J. Intracellular transport of pancreatic zymogens during caerulein supramaximal stimulation. Am. J. Physiol. 1987, 253, G517-G526. [PubMed]

58. Sah, R.P.; Saluja, A. Molecular mechanisms of pancreatic injury. Curr. Opin. Gastroenterol. 2011, $27,444-451$. [CrossRef] [PubMed]

59. Robles, L.; Vaziri, N.D.; Ichii, H. Role of oxidative stress in the pathogenesis of pancreatitis: Effect of antioxidant therapy. Pancreat. Disord. Ther. 2013, 3, 112. [CrossRef] [PubMed]

60. Song, Y.; Buchwald, P. TNF superfamily protein-protein interactions: Feasibility of small-molecule modulation. Curr. Drug Targets 2015, 16, 393-408. [CrossRef] [PubMed]

61. Malleo, G.; Mazzon, E.; Siriwardena, A.K.; Cuzzocrea, S. TNF- $\alpha$ as a therapeutic target in acute pancreatitis-lessons from experimental models. Sci. World J. 2007, 7, 431-448. [CrossRef] [PubMed]

62. Malleo, G.; Mazzon, E.; Siriwardena, A.K.; Cuzzocrea, S. Role of tumor necrosis factor- $\alpha$ in acute pancreatitis: From biological basis to clinical evidence. Shock 2007, 28, 130-140. [CrossRef] [PubMed]

63. Papachristou, G.I. Prediction of severe acute pancreatitis: Current knowledge and novel insights. World J. Gastroenterol. 2008, 14, 6273-6275. [CrossRef] [PubMed]

64. Hart, P.H.; Vitti, G.F.; Burgess, D.R.; Whitty, G.A.; Piccoli, D.S.; Hamilton, J.A. Potential anti-inflammatory effects of interleukin 4: Suppression of human monocyte tumor necrosis factor $\alpha$, interleukin 1, and prostaglandin E2. Proc. Natl. Acad. Sci. USA 1989, 86, 3803-3807. [CrossRef] [PubMed]

65. Vannier, E.; Miller, L.C.; Dinarello, C.A. Coordinated anti-inflammatory effects of interleukin 4: Interleukin 4 suppresses interleukin 1 production but up-regulates gene expression and synthesis of interleukin 1 receptor antagonist. Proc. Natl. Acad. Sci. USA 1992, 89, 4076-4080. [CrossRef] [PubMed]

66. Zhang, C.; Ge, C.L.; Guo, R.X.; He, S.G. Effect of IL-4 on altered expression of complement activation regulators in rat pancreatic cells during severe acute pancreatitis. World J. Gastroenterol. 2005, 11, 6770-6774. [CrossRef] [PubMed]

67. Kilciler, G.; Musabak, U.; Bagci, S.; Yesilova, Z.; Tuzun, A.; Uygun, A.; Gulsen, M.; Oren, S.; Oktenli, C.; Karaeren, N. Do the changes in the serum levels of IL-2, IL-4, TNF $\alpha$, and IL-6 reflect the inflammatory activity in the patients with post-ERCP pancreatitis? Clin. Dev. Immunol. 2008, 2008, 481560. [CrossRef] [PubMed]

68. Xue, J.; Sharma, V.; Hsieh, M.H.; Chawla, A.; Murali, R.; Pandol, S.J.; Habtezion, A. Alternatively activated macrophages promote pancreatic fibrosis in chronic pancreatitis. Nat. Commun. 2015, 6, 7158. [CrossRef] [PubMed]

69. Gullo, L.; Cavicchi, L.; Tomassetti, P.; Spagnolo, C.; Freyrie, A.; D'Addato, M. Effects of ischemia on the human pancreas. Gastroenterology 1996, 111, 1033-1038. [CrossRef]

70. Lonardo, A.; Grisendi, A.; Bonilauri, S.; Rambaldi, M.; Selmi, I.; Tondelli, E. Ischemic necrotizing pancreatitis after cardiac surgery. A case report and review of the literature. Ital. J. Gastroenterol. Hepatol. 1999, 31, 872-875. [PubMed]

71. Warshaw, A.L.; O'Hara, P.J. Susceptibility of the pancreas to ischemic injury in shock. Ann. Surg. 1978, 188, 197-201. [CrossRef] [PubMed]

72. Sakorafas, G.H.; Tsiotos, G.G.; Bower, T.C.; Sarr, M.G. Ischemic necrotizing pancreatitis. Two case reports and review of literature. Int. J. Pancreatol. 1998, 24, 117-121. [PubMed]

73. Vollmar, B.; Menger, M.D. Microcirculatory dysfunction in acute pancreatitis. A new concept of pathogenesis involving vasomotion-associated arteriolar constriction and dilation. Pancreatology 2003, 3, 181-190. [CrossRef] [PubMed]

74. Waldner, H. Vascular mechanisms to induce acute pancreatitis. Eur. Surg. Res. 1992, 24 (Suppl. S1), 62-67. [CrossRef] [PubMed]

75. Ceranowicz, P.; Cieszkowski, J.; Warzecha, Z.; Dembiński, A. Experimental models of acute pancreatitis. Postep. Hig. Med. Doswiadczalnej 2015, 69, 264-269. [CrossRef] [PubMed]

76. Dembiński, A.; Warzecha, Z.; Ceranowicz, P.; Stachura, J.; Tomaszewska, R.; Konturek, S.J.; Sendur, R.; Dembiński, M.; Pawlik, W.W. Pancreatic damage and regeneration in the course of ischemia-induced acute pancreatitis in rats. J. Physiol. Pharmacol. 2001, 52, 221-236. [PubMed]

77. Klar, E.; Messmer, K.; Warshaw, A.L.; Herfarth, C. Pancreatic ischemia in experimental acute pancreatitis: Mechanism, significance and therapy. Br. J. Surg. 1990, 77, 1205-1210. [CrossRef] [PubMed] 
78. Warzecha, Z.; Dembinski, A.; Ceranowicz, P.; Konturek, S.J.; Tomaszewska, R.; Stachura, J.; Konturek, P.C. IGF-1 stimulates production of interleukin-10 and inhibits development of caerulein-induced pancreatitis. J. Physiol. Pharmacol. 2003, 54, 575-590. [PubMed]

79. Hernández-Barbáchano, E.; San Román, J.I.; López, M.A.; Coveñas, R.; López-Novoa, J.M.; Calvo, J.J. Beneficial effects of vasodilators in preventing severe acute pancreatitis shock. Pancreas 2006, 32, 335-342. [CrossRef] [PubMed]

80. Feldman, B.F.; Attix, E.A.; Strombeck, D.R.; O'Neill, S. Biochemical and coagulation changes in a canine model of acute necrotizing pancreatitis. Am. J. Vet. Res. 1981, 42, 805-809. [PubMed]

81. Lasson, A.; Ohlsson, K. Consumptive coagulopathy, fibrinolysis and protease-antiprotease interactions during acute human pancreatitis. Thromb. Res. 1986, 41, 167-183. [CrossRef]

82. Salomone, T.; Tosi, P.; Palareti, G.; Tomassetti, P.; Migliori, M.; Guariento, A.; Saieva, C.; Raiti, C.; Romboli, M.; Gullo, L. Coagulative disorders in human acute pancreatitis: Role for the D-dimer. Pancreas 2003, 26, 111-116. [CrossRef] [PubMed]

83. Maeda, K.; Hirota, M.; Ichihara, A.; Ohmuraya, M.; Hashimoto, D.; Sugita, H.; Takamori, H.; Kanemitsu, K.; Baba, H. Applicability of disseminated intravascular coagulation parameters in the assessment of the severity of acute pancreatitis. Pancreas 2006, 32, 87-92. [CrossRef] [PubMed]

84. Kakafika, A.; Papadopoulos, V.; Mimidis, K.; Mikhailidis, D.P. Coagulation, platelets, and acute pancreatitis. Pancreas 2007, 34, 15-20. [CrossRef] [PubMed]

85. Qiu, F.; Lu, X.S.; Huang, Y.K. Effect of low molecular weight heparin on pancreatic micro-circulation in severe acute pancreatitis in a rodent model. Chin. Med. J. 2007, 120, 2260-2263. [PubMed]

86. Ceranowicz, P.; Dembinski, A.; Warzecha, Z.; Dembinski, M.; Cieszkowski, J.; Rembisz, K.; Konturek, S.J.; Kusnierz-Cabala, B.; Tomaszewska, R.; Pawlik, W.W. Protective and therapeutic effect of heparin in acute pancreatitis. J. Physiol. Pharmacol. 2008, 59 (Suppl. S4), 103-125. [PubMed]

87. Ceranowicz, P.; Dembiński, M.; Warzecha, Z.; Cieszkowski, J.; Kuśnierz-Cabala, B.; Tomaszewska, R.; Dembiński, A. Healing effect of heparin in the course of edematous, cerulein-induced acute pancreatitis. Przeglad. Gastroenterol. 2009, 4, 199-205.

88. Ke, L.; Ni, H.B.; Tong, Z.H.; Li, W.Q.; Li, N.; Li, J.S. Efficacy of continuous regional arterial infusion with low-molecular-weight heparin for severe acute pancreatitis in a porcine model. Shock 2014, 41, 443-448. [CrossRef] [PubMed]

89. Warzecha, Z.; Sendur, P.; Ceranowicz, P.; Dembinski, M.; Cieszkowski, J.; Kusnierz-Cabala, B.; Tomaszewska, R.; Dembinski, A. Pretreatment with low doses of acenocoumarol inhibits the development of acute ischemia/reperfusion-induced pancreatitis. J. Physiol. Pharmacol. 2015, 66, 731-740. [PubMed]

90. Warzecha, Z.; Sendur, P.; Ceranowicz, P.; Dembiński, M.; Cieszkowski, J.; Kuśnierz-Cabala, B.; Olszanecki, R.; Tomaszewska, R.; Ambroży, T.; Dembiński, A. Protective Effect of Pretreatment with Acenocoumarol in Cerulein-Induced Acute Pancreatitis. Int. J. Mol. Sci. 2016, 17, E1709. [CrossRef] [PubMed]

91. Rabenstein, T.; Roggenbuck, S.; Framke, B.; Martus, P.; Fischer, B.; Nusko, G.; Muehldorfer, S.; Hochberger, J.; Ell, C.; Hahn, E.G.; et al. Complications of endoscopic sphincterotomy: Can heparin prevent acute pancreatitis after ERCP? Gastrointest. Endosc. 2002, 55, 476-483. [CrossRef] [PubMed]

92. Ung, K.A.; Rydberg, L.; Modin, S.; Kylebäck, A.; Modin, M. A preventive effect of unfractionated heparin on post-ERCP pancreatitis is suggested by positive effects on laboratory markers. Hepatogastroenterology 2011, 58, 168-173. [PubMed]

93. Alagözlü, H.; Cindoruk, M.; Karakan, T.; Unal, S. Heparin and insulin in the treatment of hypertriglyceridemia-induced severe acute pancreatitis. Dig. Dis. Sci. 2006, 51, 931-933. [CrossRef] [PubMed]

94. Date, Y.; Murakami, N.; Toshinai, K.; Matsukura, S.; Niijima, A.; Matsuo, H.; Kangawa, K.; Nakazato, M. Nerve ablation showed a tendency to induce an additional increase in pancreas mass and pancreatic blood flow. Gastroenterology 2002, 123, 1120-1128. [CrossRef] [PubMed]

95. Gukovskaya, A.S.; Gukovsky, I.; Zaninovic, V.; Song, M.; Sandoval, D.; Gukovsky, S.; Pandol, S.J. Pancreatic acinar cells produce, release, and respond to tumor necrosis factor- $\alpha$. Role in regulating cell death and pancreatitis. J. Clin. Investig. 1997, 100, 1853-1862. [CrossRef] [PubMed]

96. Rakonczay, Z.; Takács, T.; Boros, I.; Lonovics, J. Heat shock proteins and the pancreas. J. Cell. Physiol. 2003, 195, 383-391. [CrossRef] [PubMed] 
97. Robert, J.; Ménoret, A.; Basu, S.; Cohen, N.; Srivastava, P.R. Phylogenetic conservation of the molecular and immunological properties of the chaperones GP96 and HSP70. Eur. J. Immunol. 2001, 31, 186-195. [CrossRef]

98. Frossard, J.L.; Bhagat, L.; Lee, H.S.; Hietaranta, A.J.; Singh, V.P.; Song, A.M.; Steer, M.L.; Saluja, A.K. Both thermal and non-thermal stress protect against caerulein induced pancreatitis and prevent trypsinogen activation in the pancreas. Gut 2002, 50, 78-83. [CrossRef] [PubMed]

99. Tashiro, M.; Ernst, S.A.; Edwards, J.; Williams, J.A. Hyperthermia induces multiple pancreatic heat shock proteins and protects against subsequent arginine-induced acute pancreatitis in rats. Digestion 2002, 65, 118-126. [CrossRef] [PubMed]

100. Rakonczay, Z.; Takács, T.; Iványi, B.; Mándi, Y.; Pápai, G.; Boros, I.; Varga, I.S.; Jost, K.; Lonovics, J. The effects of hypo- and hyperthermic pretreatment on sodium taurocholate-induced acute pancreatitis in rats. Pancreas 2002, 24, 83-89. [CrossRef] [PubMed]

101. Warzecha, Z.; Dembinski, A.; Ceranowicz, P.; Konturek, S.J.; Dembinski, M.; Pawlik, W.W.; Tomaszewska, R.; Stachura, J.; Kusnierz-Cabala, B.; Naskalski, J.W.; et al. Ischemic preconditioning inhibits development of edematous cerulein-induced pancreatitis: Involvement of cyclooxygenases and heat shock protein 70. World J. Gastroenterol. 2005, 11, 5958-5965. [CrossRef] [PubMed]

102. Takayama, S.; Reed, J.C.; Homma, S. Heat-shock proteins as regulators of apoptosis. Oncogene 2003, 22, 9041-9047. [CrossRef] [PubMed]

103. Weber, C.K.; Gress, T.; Müller-Pillasch, F.; Lerch, M.M.; Weidenbach, H.; Adler, G. Supramaximal secretagogue stimulation enhances heat shock protein expression in the rat pancreas. Pancreas 1995, 10, 360-367. [CrossRef] [PubMed]

104. Konturek, P.C.; Dembinski, A.; Warzecha, Z.; Burnat, G.; Ceranowicz, P.; Hahn, E.G.; Dembinski, M.; Tomaszewska, R.; Konturek, S.J. Pioglitazone, a specific ligand of peroxisome proliferator-activated receptor- $\gamma$, protects pancreas against acute cerulein-induced pancreatitis. World J. Gastroenterol. 2005, 11, 6322-6329. [CrossRef] [PubMed]

105. Jaworek, J.; Bonior, J.; Tomaszewska, R.; Jachimczak, B.; Kot, M.; Bielański, W.; Pawlik, W.W.; Sendur, R.; Stachura, J.; Konturek, P.C.; et al. Involvement of cyclooxygenase-derived prostaglandin E2 and nitric oxide in the protection of rat pancreas afforded by low dose of lipopolysaccharide. J. Physiol. Pharmacol. 2001, 52, 107-126. [PubMed]

106. Jaworek, J.; Bonior, J.; Nawrot, K.; Leja, A.; Sendur, R.; Stachura, J.; Pawlik, W.; Konturek, S. Intracerebroventricular administration of bacterial lipopolysaccharide prevents the development of acute experimental pancreatitis in the rat. Med. Sci. Monit. 2002, 8, BR136-BR143. [PubMed]

107. Jaworek, J.; Jachimczak, B.; Bonior, J.; Kot, M.; Tomaszewska, R.; Karczewska, E.; Stachura, J.; Pawlik, W.; Konturek, S.J. Protective role of endogenous nitric oxide (NO) in lipopolysaccharide-induced pancreatic damage (a new experimental model of acute pancreatitis). J. Physiol. Pharmacol. 2000, 51, 85-102. [PubMed]

108. Jaworek, J.; Leja-Szpak, A.; Bonior, J.; Nawrot, K.; Tomaszewska, R.; Stachura, J.; Sendur, R.; Pawlik, W.; Brzozowski, T.; Konturek, S.J. Protective effect of melatonin and its precursor L-tryptophan on acute pancreatitis induced by caerulein overstimulation or ischemia/reperfusion. J. Pineal Res. 2003, 34, 40-52. [CrossRef] [PubMed]

109. Tomaszewska, R.; Dembiński, A.; Warzecha, Z.; Ceranowicz, P.; Stachura, J. Morphological changes and morphological-functional correlations in acute experimental ischemia/reperfusion pancreatitis in rats. Pol. J. Pathol. 2000, 51, 179-184. [PubMed]

110. Warzecha, Z.; Sendur, P.; Ceranowicz, P.; Cieszkowski, J.; Dembiński, M.; Sendur, R.; Bonior, J.; Jaworek, J.; Ambroży, T.; Olszanecki, R.; et al. Therapeutic effect of low doses of acenocoumarol in the course of ischemia/reperfusion-induced acute pancreatitis in rats. Int. J. Mol. Sci. 2017, 18, 882. [CrossRef] [PubMed]

111. Bonior, J.; Ceranowicz, P.; Gajdosz, R.; Kuśnierz-Cabala, B.; Pierzchalski, P.; Warzecha, Z.; Dembiński, A.; Pędziwiatr, M.; Kot, M.; Leja-Szpak, A.; et al. Molecular ghrelin system in the pancreatic acinar cells: The role of the polypeptide, caerulein and sensory nerves. Int. J. Mol. Sci. 2017, 18, 929. [CrossRef] [PubMed]

112. Amsterdam, A.; Solomon, T.E.; Jamieson, J.D. Sequential dissociation of the exocrine pancreas into lobules, acini, and individual cells. Methods Cell Biol. 1978, 20, 361-378. [PubMed]

113. Konturek, S.J.; Dembinski, A.; Konturek, P.J.; Warzecha, Z.; Jaworek, J.; Gustaw, P.; Tomaszewska, R.; Stachura, J. Role of platelet activating factor in pathogenesis of acute pancreatitis in rats. Gut 1992, 33, 1268-1274. [CrossRef] [PubMed] 
114. Zaninovic, V.; Gukovskaya, A.S.; Gukovsky, I.; Mouria, M.; Pandol, S.J. Cerulein upregulates ICAM-1 in pancreatic acinar cells, which mediates neutrophil adhesion to these cells. Am. J. Physiol. Gastrointest. Liver Physiol. 2000, 279, G666-G676. [PubMed]

115. Bonior, J.; Jaworek, J.; Kot, M.; Konturek, S.J.; Pierzchalski, P. Long-lasting effect of infant rats endotoxemia on heat shock protein 60 in the pancreatic acinar cells: Involvement of toll-like receptor 4. Int. J. Inflamm. 2012, 2012, 354904. [CrossRef] [PubMed]

116. Chomczynski, P.; Sacchi, N. Single-step method of RNA isolation by acid guanidinium thiocyanate-phenol-chloroform extraction. Anal. Biochem. 1987, 162, 156-159. [CrossRef]

117. Nudel, U.; Zakut, R.; Shani, M.; Neuman, S.; Levy, Z.; Yaffe, D. The nucleotide sequence of the rat cytoplasmic $\beta$-actin gene. Nucleic Acids Res. 1983, 11, 1759-1771. [CrossRef] [PubMed]

118. Shirai, T.; Shimuzu, N.S.; Horiguchi, S.; Ito, H. Cloning and expression in Escherichia coli of the gene for rat tumor necrosis factor. Agric. Biol. Chem. 1989, 53, 1733-1736. [CrossRef]

119. Sambrook, J.; Fritsch, E.F.; Maniatis, T. Molecular Cloning: A Laboratory Manual, 2nd ed.; Cold Spring Harbor Laboratory Press: New York, NY, USA, 1989.

(C) 2017 by the authors. Licensee MDPI, Basel, Switzerland. This article is an open access article distributed under the terms and conditions of the Creative Commons Attribution (CC BY) license (http://creativecommons.org/licenses/by/4.0/). 